\title{
Thermal evolution and shale gas potential estimation of the Wealden and Posidonia Shale in NW-Germany and the Netherlands: a 3D basin modelling study
}

\author{
B. Bruns, ${ }^{*}$ R. Littke, ${ }^{*}$ M. Gasparik,* J.-D. van Wees $\uparrow, \$$ and S. Nelskamp $\dagger$ \\ *Institute for Geology and Geochemistry of Petroleum and Coal, Energy and Mineral Resources (EMR), \\ RWTH Aachen University, Aachen, Germany \\ $\dagger$ Netherlands Institute for Applied Geosciences TNO, Utrecht, the Netherlands \\ $¥$ Department of Earth Sciences, Utrecht University, Utrecht, the Netherlands
}

\begin{abstract}
Sedimentary basins in NW-Germany and the Netherlands represent potential targets for shale gas exploration in Europe due to the presence of Cretaceous (Wealden) and Jurassic (Posidonia) marlstones/shales as well as various Carboniferous black shales. In order to assess the regional shale gas prospectivity of this area, a 3D high-resolution petroleum system model has been compiled and used to reconstruct the source-rock maturation based on calibrated burial and thermal histories. Different basal heat flow scenarios and accordingly, different high-resolution scenarios of erosional amount distribution were constructed, incorporating all major uplift events that affected the study area. The model delivers an independent 3D reappraisal of the tectonic and thermal history that controlled the differential geodynamic evolution and provides a high-resolution image of the maturity distribution and evolution throughout the study area and the different basins. Pressure, temperature and TOCdependent gas storage capacity and gas contents of the Posidonia Shale and Wealden were calculated based on experimentally derived Langmuir sorption parameters and newly compiled source-rock thickness maps indicating shale gas potential of the Lower Saxony Basin, southern Gifhorn Trough and West Netherlands Basin.
\end{abstract}

\section{INTRODUCTION}

Sedimentary basins in NW-Germany and the Netherlands represent potential targets for shale gas/shale oil exploration due to the presence of Lower Cretaceous lacustrine (Wealden; Rippen et al., 2013) and Jurassic marine (Posidonia Shale) organic-rich marlstones and shales as well as various Carboniferous black shales (Littke et al., 2011; Andruleit et al., 2012; Uffmann et al., 2012). The Lower Jurassic Posidonia Shale is the most important source rock for conventional oil exploration in this area (Leythaeuser et al., 1988; Wehner, 1997; Blumenstein et al., 2008) but is also one of the most promising candidates for unconventional shale gas/oil exploration (Andruleit et al., 2012) besides the Lower Cretaceous Wealden Shale.

Unlike in conventional reservoirs in which gas is stored primarily as compressed ('free') gas in the intragranular pore space and fractures, a significant proportion of gas in shales can be stored as 'sorbed' gas. The sorption of hydrocarbon gas (mostly methane) in shales provides gas storage capacity in addition to the 'free gas' capacity in

Correspondence: R. Littke, Energy and Mineral Resources Group, Institute of Geology and Geochemistry of Petroleum and Coal, RWTH Aachen University, Lochnerstr. 4-20, 52056 Aachen, Germany. E-mail: ralf.littke@emr.rwth-aachen.de the pore system. The methane sorption is considered to take place predominantly within the microporous organic matter (kerogen) and is controlled by the Total Organic Carbon (TOC), kerogen type, maturity, water saturation and to some extent by the inorganic constituents (clay minerals).

Numerous basin modelling studies have been performed in that area, comprising 1D, 2D and 3D modelling approaches (e.g. Petmecky et al., 1999; Senglaub et al., 2005; Uffmann et al., 2010; Nelskamp, 2011). In these studies, the tectonic evolution as well as source-rock maturation has been investigated partly in order to analyse the conventional petroleum systems. Whereas 3D modelling studies covering the whole area have been lacking a detailed resolution sufficient enough for exploration and prospect evaluation, 1D and 2D models are generally missing important influence factors on pressure, temperature and hydrocarbon migration that can only be accurately addressed in three dimensions (Bruns et al., 2013).

Quantification of the total storage capacity, including sorbed gas and free gas is a prerequisite for estimations of resource potential and technically recoverable amounts of gas at given reservoir conditions. In early exploration phases, 3D basin modelling with integrated sorption modules together with the simulation of the burial history, gas generation/expulsion and consideration of organic matter-hosted porosity is a valuable tool 
to reduce the exploration risk. In addition, an accurate reconstruction of the source-rock maturation through geologic time and within the different basins is crucial for the assessment of petroleum generation and storage.

This study was performed in order to improve the understanding of shale gas potential in the study area by linking experimental petrophysical work addressing the source-rock sorption capacity with high-resolution 3D basin modelling addressing the reconstruction of the tectonic and thermal evolution. Therefore, a 3D basin model of the present-day configuration of NW-Germany and the Netherlands was compiled and used as a base for forward simulation of the basin evolution. The burial as well as the erosion histories have been calibrated and constrained by well data at 731 locations. Being based on different basal heat flow scenarios, this study provides different high-resolution scenarios of erosional amount distribution, incorporating all major uplift events that affected the study area. The different heat flow and erosion scenarios in this model provide further constraints on the maturity evolution of the different basins in the study area. Thus, based on the thermally calibrated geodynamic evolution, petroleum generation, migration and accumulation in the Posidonia Shale and Wealden, the evolution of gas storage capacity and sorbed gas masses have been modelled using refined kinetic data and experimentally derived Langmuir sorption parameters delivering important qualitative information on the regional distribution of shale gas potential.

\section{GEODYNAMIC EVOLUTION}

The differentiation between basins, highs and platforms in the study area (Fig. 1) developed in response to global plate movement and responding changes in lithosphere structure and stress field (Cloetingh \& Ziegler, 2007; Maystrenko et al., 2008). The main tectonic events that affected the Netherlands and NW-Germany comprise the Caledonian and Variscan orogenies due to amalgamation of Pangaea during the Paleozoic, Mesozoic rifting accompanying the breakup of Pangaea, the Alpine orogeny induced by the collision of Europe and Africa during the Upper Cretaceous/Lower Tertiary and the Oligocene to recent rifting of the Rhine Graben system (Senglaub et al., 2006; de Jager, 2007). As a result, multiple phases of uplift and basin inversion occurred in different parts of the study area. The following description will focus on the major tectonic events that induced uplift and basin inversion. A more detailed summary of tectonic processes and their influence on the structural evolution of NW-Germany has already been provided in Bruns et al. (2013).

During the Middle to Upper Devonian the convergence of Gondwana and Laurussia started, resulting in full-scale Himalayan-type collision forming the Variscan orogeny during the Visean (Franke, 2000). The Variscan fold-and-thrust belt propagated northwards reaching its final position just south of the Netherlands (Oncken et al., 2000). Today the Variscan Deformation Front strikes approximately E-W through Belgium and SW-NE into Germany. Crustal shortening and inversion ceased during the Upper Pennsylvanian (Ziegler, 1990). Wrench tectonics created several structural features, e.g. the Campine Basin and Roer Valley Graben (Duin et al., 2006) and induced erosion of Upper Carboniferous deposits in different areas. The Hunze Formation (Westphalian D - Stephanian) was eroded in most parts of the Netherlands except the Campine Basin (future Zeeland Platform - West Netherlands Basin). In NW-Germany, Stephanian strata are unconformably overlying partly

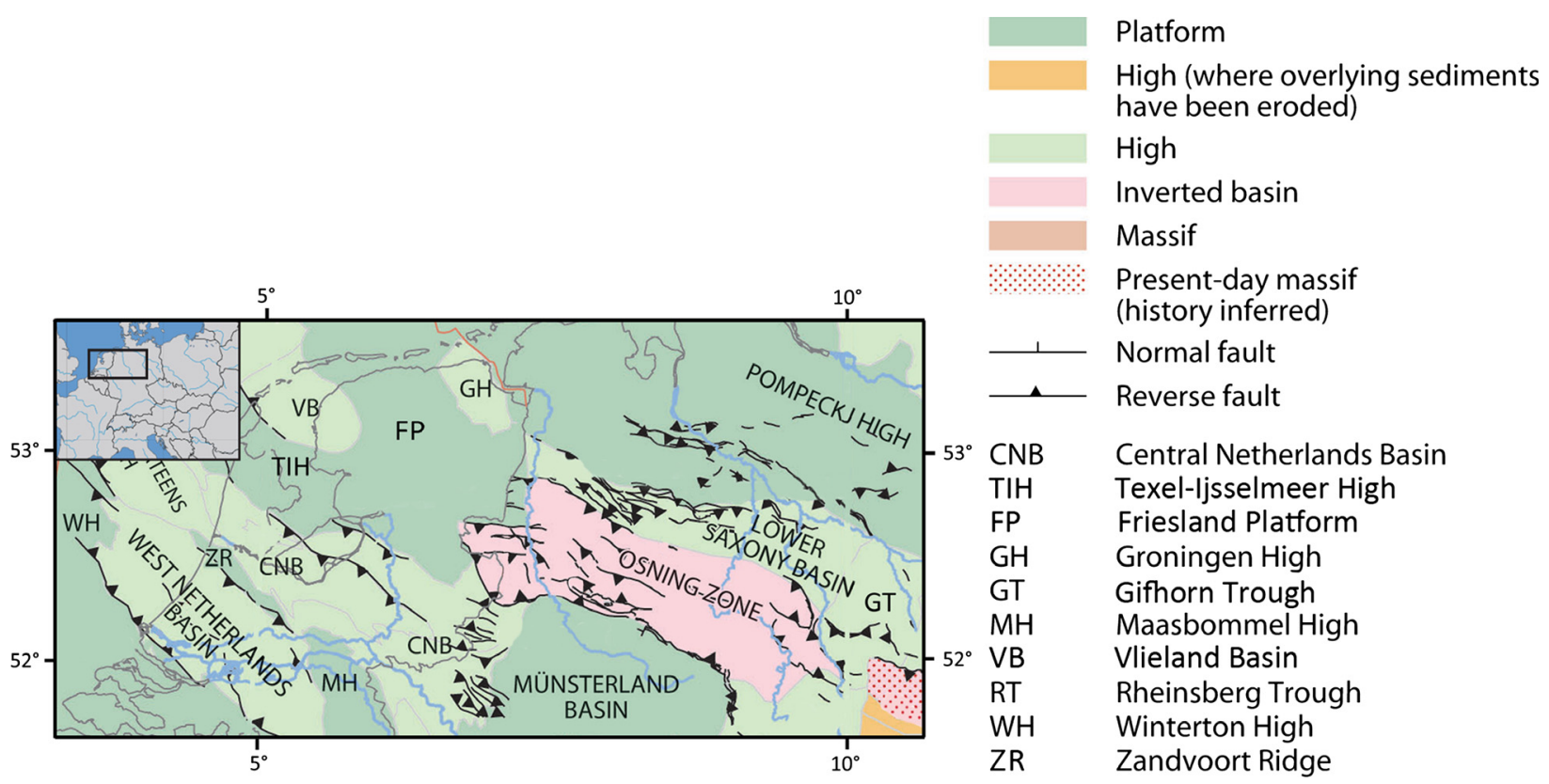

Fig. 1. Structural elements and Upper Cretaceous tectonic evolution (modified from Doornenbal \& Stevenson, 2010; van Balen et al., 2005). 


\section{B. Bruns et al.}

eroded Westphalian C-D deposits. In the study area, uplift was most dominant in the Münsterland Basin and eastern Lower Saxony Basin, the central part of the West Netherlands Basin, the Zandvoort Ridge, and the Friesland Platform (Fig. 1; Littke et al., 1994; Nelskamp, 2011).

Rifting related to the Mesozoic breakup of Pangaea and opening of the Atlantic induced transtensional development of sub-basins including the Lower Saxony Basin, the Roer Valley Graben, West Netherlands, Central Netherlands, Broad Fourteens, and Vlieland basins during the Middle Jurassic to Lower Cretaceous (Upper Kimmerian) rifting. Simultaneously, adjacent platforms were uplifted and deeply truncated resulting in the widely recognized Upper Kimmerian Unconformity (Lower Cretaceous) which was accompanied by a regional sealevel low-stand (de Jager, 2007). This uplift affected, e.g. the Pompeckj Basin and Münsterland Basin. Whereas in NW-Germany quite homogeneous sediment thicknesses can be observed in the areas of the Pompeckj Basin and Lower Saxony Basin, basin differentiation in the Netherlands already started during the Upper Triassic indicated by increased sediment thicknesses in the area of the basins, especially in the Central and West Netherlands basins and decreased thicknesses in the surrounding highs (Geluk, 2007).

During the Upper Cretaceous the convergence of Africa and Europe, closing the Tethys system of oceanic basins, induced the gradual development of the Alpine orogeny. Most authors (e.g. Ziegler et al., 1995; Marotta et al., 2001; Krzywiec, 2006) have interpreted the Subhercynian and Laramide compressional/transpressional inversion of Mesozoic extensional/transtensional basins as a consequence of the collision of the Alpine-Carpathian Orogeny with Europe's southern margin in a classic orogenic foreland collision model. Kley \& Voigt (2008), however, have presented an alternative hypothesis, in which the Upper Cretaceous kinematic history of the two regions does not seem to be compatible. The location of the Adria Plate and evolving Alpine chain in recent plate reconstructions (e.g. Stampfli \& Borel, 2004) indicate that the distance to central Europe was too far, incorporating an oceanic basin in between. They proposed that this event only reflects the onset of the Africa-Iberia-Europe convergence as the Alpine collision with southern Europe did not commence until Paleocene or Eocene times. Instead, basin inversion during the Cretaceous was caused by the West-Central Europe's thin lithosphere being pinched between the East European Platform and Africa (Doornenbal \& Stevenson, 2010). East of the Netherlands (Polish Trough, North German and Lower Saxony basins) the inversion ceased during the Upper Cretaceous to earliest Tertiary. In the Netherlands (Broad Fourteens and West Netherlands basins), it continued until Upper Oligocene to Lower Miocene times (van Hoorn, 1987; Ziegler, 1990; Ziegler et al., 1995; de Lugt et al., 2003; de Jager, 2007) which might be related to a delayed mechanical coupling of the collisional system towards the west, i.e. between the Pyrenean Orogeny and central Europe (Doornenbal \& Stevenson, 2010). Despite the difference in timing of this erosion event between Germany and the Netherlands, it is summarized and named 'Subhercynian' in the following.

\section{METHODS}

The emphasis of this study was to build a 3D basin model of the study area in order to test different burial history scenarios. This procedure leads to a best-fit setting which in turn can be used for creating scenarios of petroleum generation, adsorption and accumulation constrained by the tectonic evolution and source-rock maturation. Numerical modelling was performed using the PetroMod $^{\circledR}$ software suite v.2012.1 (Schlumberger AaTC, Aachen, Germany). Numerical basin modelling provides an integrated approach to understand and reconstruct significant geological developments occurring during the basin evolution and can be understood as a dynamic forward modelling approach of these geological processes in sedimentary basins over geological time periods. The simulation starts with the deposition of the oldest layer and continues until the present-day geometry is reached. During simulation various geological, geochemical and petrophysical processes are calculated and updated at each defined time step and for each model grid cell. This simulation covers, i.e. (de-)compaction, pore pressure calculation as well as temperature and heat flow analysis based on the evolution of thermal maturity parameters (e.g. vitrinite reflectance, biomarkers), modelling of hydrocarbon generation and accumulation, fluid migration and petroleum compositional analysis (Hantschel \& Kauerauf, 2009).

\section{Basin geometry reconstruction}

The reconstruction of the present-day geometry of a joint basin model of the Dutch and NW-German area has been accomplished by merging different depth horizon interpretations into a single $3 \mathrm{D}$ interpretation (Table 1). Additionally, an underlying basement layer with an average thickness of $10000 \mathrm{~m}$ and a base depth of $17000 \mathrm{~m}$ has been added. A varying vertical pseudoresolution or maximum cell thickness (up to $400 \mathrm{~m}$ ) has been applied to the model, which is particularly important when modelling transfer of effective stress, hydrocarbon migration, etc. from one cell to another. The model consists of 23 different stratigraphic layers excluding the basement layer, covering a present-day depth interval of up to $12 \mathrm{~km}$ from top to bottom. The model comprises an area of $74660 \mathrm{~km}^{2}$ with a lateral extent up to $476 \times 255 \mathrm{~km}$ and an overall grid cell size of $1 \times 1 \mathrm{~km}$ (Fig. 2). The combination of horizontal and vertical resolution as well as study area size sums up to a total number of $c a .8$ Mio. grid cells. 
Table 1. Source, resolution and applied areas of the different stratigraphic units included in the 3D model

\begin{tabular}{|c|c|c|c|}
\hline $\begin{array}{l}\text { Stratigraphic } \\
\text { units }\end{array}$ & Sources & $\begin{array}{l}\text { Initial } \\
\text { resolution } \\
(\mathrm{m})\end{array}$ & Area \\
\hline $\begin{array}{l}\text { Surface } \\
\text { topography }\end{array}$ & $\begin{array}{l}\text { GEBCO Digital } \\
\text { Atlas (IOC, } \\
\text { IHO, BODC } \\
\text { 2003) }\end{array}$ & 4000 & $\begin{array}{l}\text { the Netherlands } \\
\text { and Germany }\end{array}$ \\
\hline \multirow[t]{2}{*}{$\begin{array}{l}\text { Mesozoic and } \\
\text { Cenozoic (incl. } \\
\text { Permian) }\end{array}$} & $\begin{array}{l}\text { NLOG } \\
\text { (www.nlog.nl, } \\
\text { v. 01/2012) }\end{array}$ & 250 & the Netherlands \\
\hline & $\begin{array}{l}\text { Geotectonic } \\
\text { Atlas of NW- } \\
\text { Germany } \\
\text { (Baldschuhn } \\
\text { et al. 1996) }\end{array}$ & 150 & Germany \\
\hline $\begin{array}{l}\text { Staßfurt } \\
\text { carbonate, } \\
\text { Permo- } \\
\text { Carboniferous } \\
\text { volcanics, } \\
\text { sedimentary } \\
\text { Rotliegend }\end{array}$ & $\begin{array}{l}\text { Maystrenko } \\
\text { et al. (2010) }\end{array}$ & 4000 & $\begin{array}{c}\text { the Netherlands } \\
\text { and Germany }\end{array}$ \\
\hline $\begin{array}{l}\text { Upper } \\
\text { Carboniferous }\end{array}$ & $\begin{array}{c}\text { Gerling et al. } \\
(1999 \mathrm{a}, \mathrm{b})\end{array}$ & 2000 & $\begin{array}{c}\text { the Netherlands } \\
\text { and Germany }\end{array}$ \\
\hline
\end{tabular}

Depositional (palaeo) layer thicknesses have been calculated based on porosity controlled backstripping of present-day thicknesses. Calculated present-day thicknesses based on backstripping are initially not identical with the given present-day thicknesses. These thickness differences, however, assist in an improved estimation of the depositional layer thicknesses in the next simulation runs. During this optimization procedure, multiple forward simulations are combined and calibrated against the present-day basin geometry until a geometry match has been realized (Hantschel \& Kauerauf, 2009). In order to achieve a sufficient match with present-day layer thicknesses and applied erosion amounts, a number of four consecutive simulation runs needed to be applied.

\section{Lithology/Facies}

For the different stratigraphic layers included in the basin model, lithological information and lateral facies distribution need to be assigned. This dataset is based on the palaeogeographic map compilations of Ziegler (1990), Gerling et al. (1999a) and Doornenbal \& Stevenson (2010). Lithologies in numerical basin modelling (PetroMoD ${ }^{\circledR}$ ) are defined by a number of petrophysical properties. This includes porosity vs. depth, permeability vs. porosity, chemical compaction parameters, seal properties, fracture limits, geomechanical behaviour, thermal conductivity vs. temperature, radiogenic heat production and heat capacity vs. temperature. A number of user-defined lithologies have been created by mixing of the standard lithologies in relation to the stratigraphic descriptions and map compilations. Above mentioned lithological properties have been automatically assigned according to the defined rock mix. Table 2 illustrates the different stratigraphic units and their depositional timing as well as the petrophysical properties of the user-defined lithologies applied in this model.

\section{Source-rock properties and kinetics}

\section{Stratigraphic framemork}

Four different stratigraphic units have source-rock properties (Table 3). Source rocks of economic importance are Carboniferous coals and black shales as well as Jurassic (Toarcian/Posidonia Shale) and Cretaceous (Berriasian/Wealden) marlstones/shales. For the sake of completeness we also included the 'Kupferschiefer'

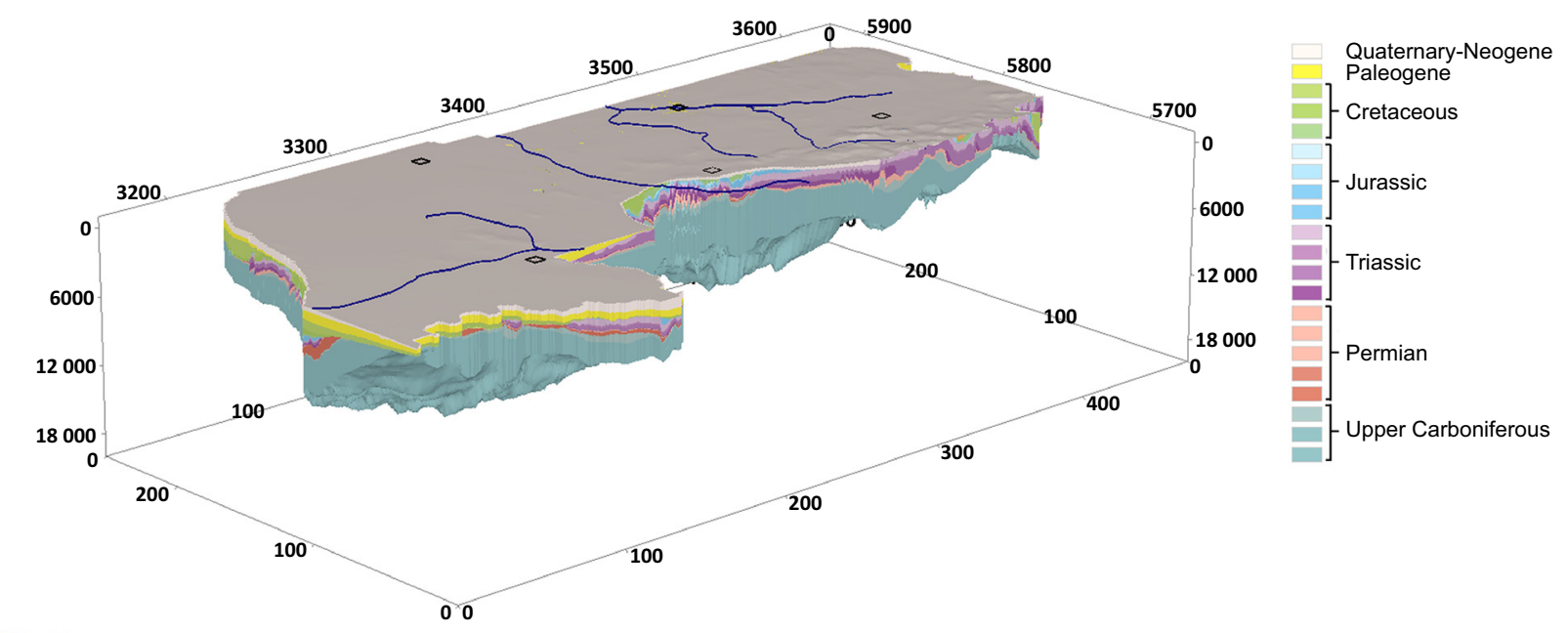

Fig. 2. View into the 3D basin model from southwest illustrating the present-day layer geometry (basement excluded, yellow arrow points to the north, vertical scale in meter, top horizontal scale in Gauss-Krüger (Zone 3) coordinates, bottom horizontal scale in km). 


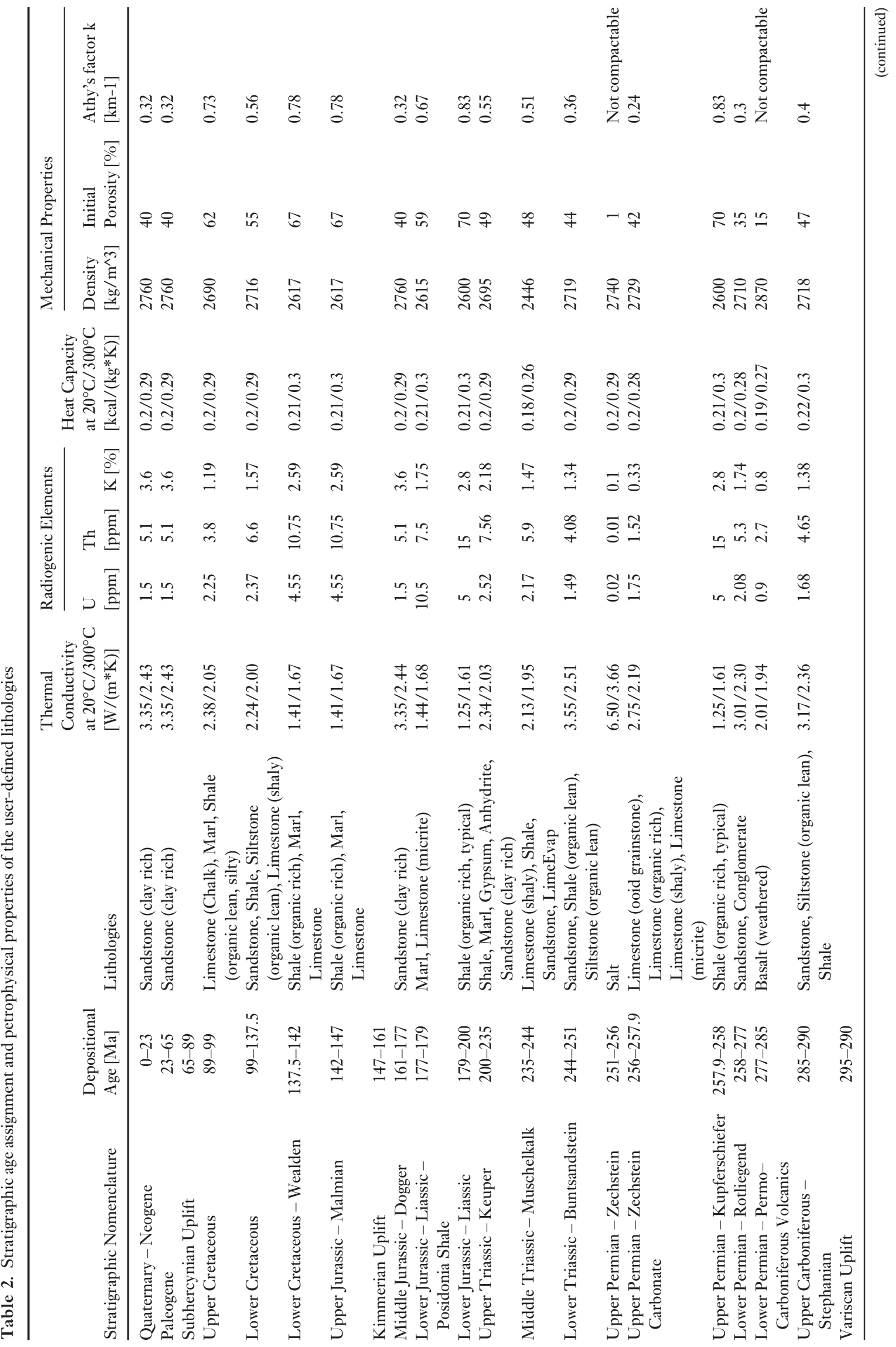




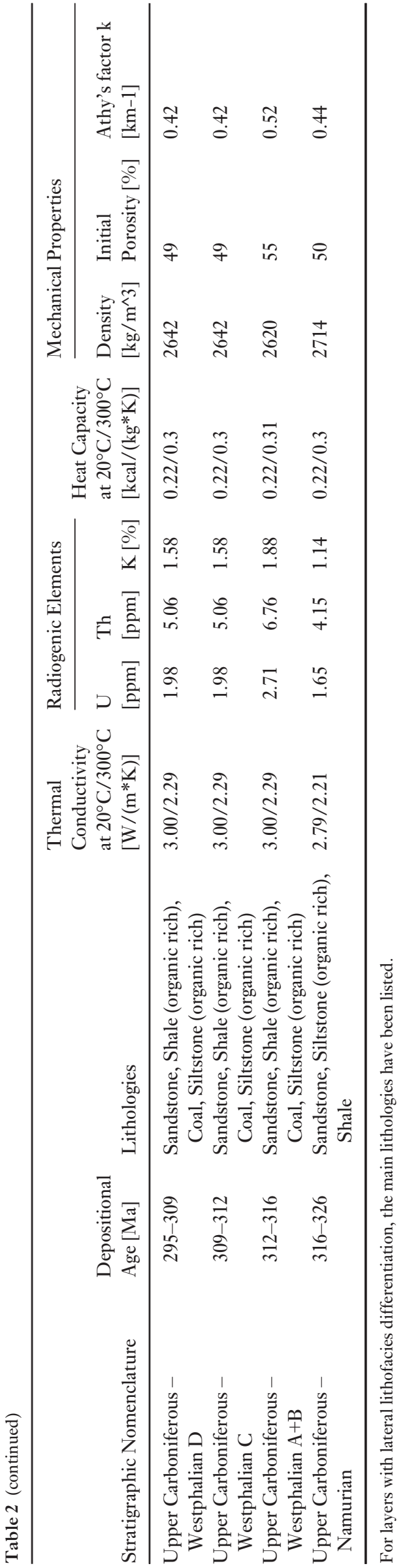

Table 3. Assigned source-rock properties

\begin{tabular}{lll}
\hline $\begin{array}{l}\text { Stratigraphic } \\
\text { unit }\end{array}$ & $\begin{array}{l}\text { Initial total } \\
\text { organic } \\
\text { carbon }(\%)\end{array}$ & $\begin{array}{l}\text { Initial hydrogen } \\
\text { index }\left(\mathrm{mgHC} \mathrm{g}^{-1} \text { TOC) }\right.\end{array}$ \\
\hline Posidonia Shale & 12 & 700 \\
Wealden & 2 & 550 \\
Westphalian & 2 & 250 \\
Kupferschiefer \& & 0.3 & 150 \\
$\quad$ Stinkkalk- & & \\
Stinkschiefer & & \\
\hline
\end{tabular}

(base of Zechstein1 cycle) and 'Stinkkalk-Stinkschiefer' (basinal equivalents to the Staßfurt Carbonate/Zechstein 2) which play a rather inferior role in this region, but are of great importance in the northeastern Central European Basin System (Resak et al., 2008).

The Upper Carboniferous Westphalian is marked by thick cyclothemic layers of coal, sand-, silt- and claystones deposited in a fluvial and deltaic environment on a coastal plain and in a tropical climate. Numerous coal seams as well as large amounts of dispersed organic matter are characteristic for Westphalian deposits (Scheidt \& Littke, 1989). This Upper Carboniferous (Pennsylvanian) coalbearing sequence is known to act as major source rock for gas in the study area (Littke et al., 1995).

During the Upper Permian Zechstein five depositional cycles $(\mathrm{Z} 1-\mathrm{Z5})$ can be distinguished, caused by repeated cut-off and reconnection to the Palaeotethys. Each is represented by marine clays, overlain by carbonates and finally salt. The stratigraphic boundaries of the Zechstein era are marked by the Kupferschiefer as the first basinwide marine layer and the Zechstein Upper Claystone Formation (ZEUC) (Nelskamp, 2011). Within the Zechstein, two layers have minor source-rock potential, the Z1 Kupferschiefer and the Z2 Stinkkalk. The salt acts as important regional seal for hydrocarbon gas within Rotliegend sandstones and Zechstein carbonates (Glennie, 1986).

In the Upper Triassic Rhaetian, global sea-level rise reestablished epicontinental marine conditions in NW-Europe. The accumulated sedimentary succession of the Altena Group (Sleen, Aalburg, Posidonia Shale, Werkendam, Brabant Formations) in the Netherlands and Liassic - Dogger Group in Germany comprises marls, carbonates, sands, and shales and culminated in the deposition of the organic-rich Toarcian black shales (Posidonia Shale).

During the uppermost Jurassic and lowermost Cretaceous (Wealden), the depositional conditions in the German part of the Lower Saxony Basin were predominantly shallow marine with some terrestrial influx (Petmecky et al., 1999). In the Aptian marine sedimentation gradually overstepped the basin margins inundating the previous highs and resulting in an overall deposition of dark coloured clastic sediments with increased concentrations of organic matter (Littke et al., 1998). 


\section{B. Bruns et al.}

\section{Kinetic data}

For these source-rock units, hydrocarbon generation was simulated using phase-predictive compositional kinetic models (di Primio \& Horsfield, 2006), consisting of a 14 component scheme and including secondary cracking (these types of compositional kinetic models are termed PhaseKinetics). The PhaseKinetics approach links source-rock organic facies to the petroleum type it generates. Using a combination of open- and closedsystem pyrolysis techniques, bulk kinetic and compositional information is acquired; gas compositions are tuned based on a GOR-gas wetness correlation from natural petroleum fluids; corrected compositions are integrated into a 14-component compositional kinetic model (C1, C2, C3, i-C4, n-C4, i-C5, n-C5, C6, C 7 $\mathrm{C}_{15}, \mathrm{C}_{16}-\mathrm{C}_{25}, \mathrm{C}_{26}-\mathrm{C}_{35}, \mathrm{C}_{36}-\mathrm{C}_{45}, \mathrm{C}_{46}-\mathrm{C}_{55}$ and $\left.\mathrm{C}_{55+}\right)$ which allows the prediction of petroleum properties. The components with more than six carbon atoms can be subjected to secondary cracking, with the assumption that the only compound generated is methane (Pepper \& Corvi, 1995a,b). The calculation of petroleum phase behaviour under the subsurface conditions of hydrocarbon migration and entrapment is possible using these methods in combination with modern basin modelling software.

\section{Source-rock thickness}

A recent depth and distribution interpretation of the Lower Jurassic (Liassic) Posidonia Shale Formation has been included which is not yet available in the public domain. For the Posidonia Shale Formation, a constant thickness of $30 \mathrm{~m}$ has been used.
Based on the cross-sections provided by Baldschuhn et al. (1996) and well data provided by TNO, a thickness map of the Wealden in Germany and the equivalent Dutch Coevorden Formation has been compiled. Based on 2140 data points in correlation with the lateral thickness distribution of the Latest Jurassic (Baldschuhn et al., 1996) this map presents the newest re-appraisal for thickness of the Wealden (Fig. 3).

\section{Sorption}

Input parameters for methane sorption on the Posidonia Shale

Gasparik et al. (2014) recently reported experimental high-pressure/high-temperature methane sorption data for Posidonia Shale samples from the studied area of the Hils Syncline, NW-Germany. In their work, excess sorption isotherms at pressures up to $25 \mathrm{MPa}$ and temperatures up to $150^{\circ} \mathrm{C}$ have been measured on a suite of Posidonia Shale samples with varying maturities. In addition, unpublished sorption data of the Wealden has been added to this study. The excess sorption isotherms were parameterized using a three-parameter $\left(n_{L}, p_{L}\right.$, $\rho_{a d s}$ ) excess sorption function based on the Langmuir function for the absolute sorption (Gasparik et al., 2014). The sorption parameters for the 'HAD-119' sample $\left(\mathrm{VR}_{r}=1.5 \%\right)$ presented in Table 4 were used in this study. The sorption parameters - Langmuir volume $\left(v_{L}\right)$ and Langmuir pressure $\left(p_{L}\right)$ - were used in the PetroMod ${ }^{\circledR}$ simulation. The TOC content of the sample is needed to scale the isotherm to the amount of kerogen available. The desorption energy parameter $\left(E_{d e s}\right)$ describes the temperature dependence of sorption

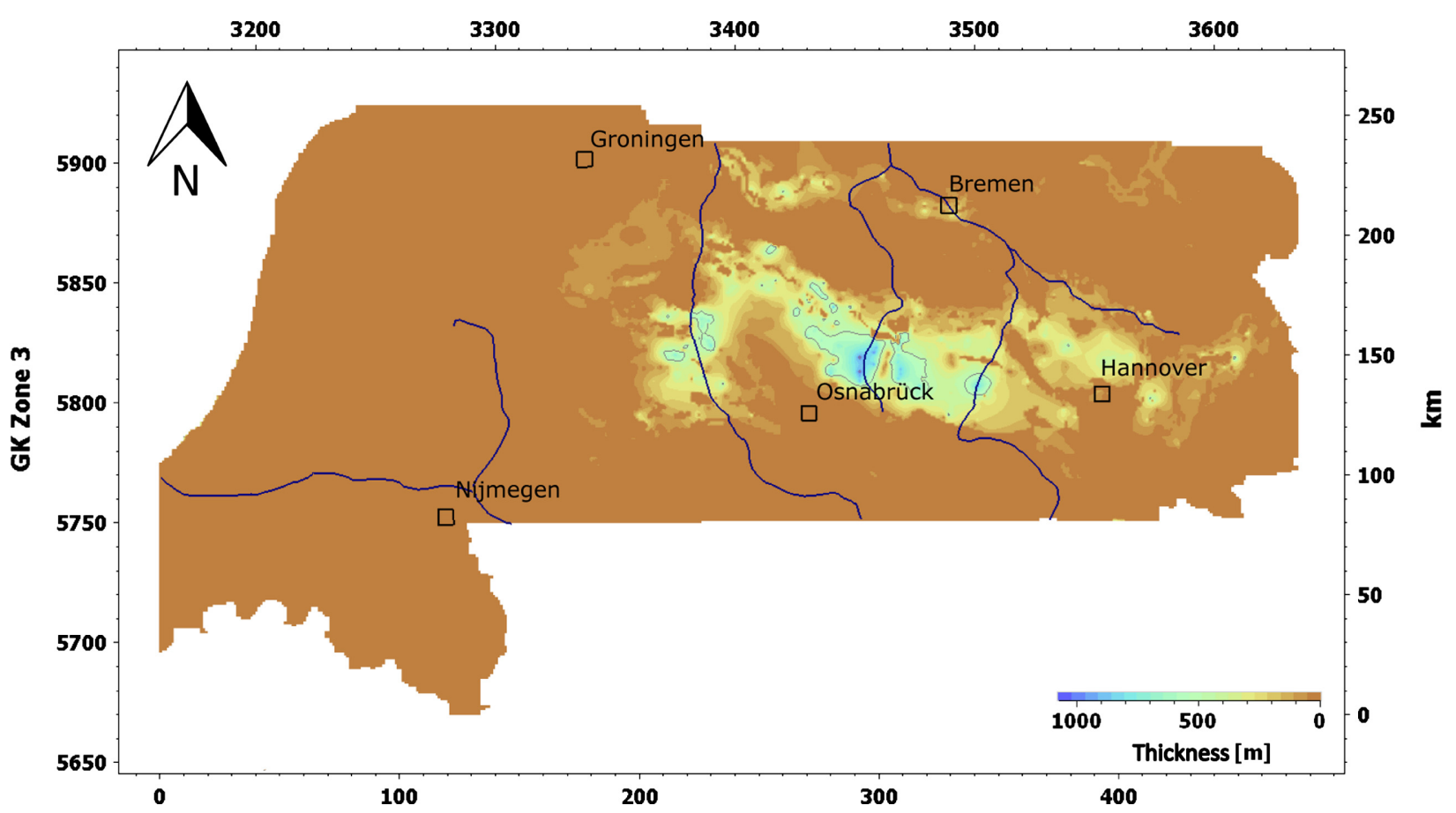

Fig. 3. Present-day Wealden thickness map (based on Baldschuhn et al., 1996; NLOG). 
Table 4. Assigned Langmuir sorption parameters

\begin{tabular}{|c|c|c|c|c|c|c|c|c|}
\hline & \multirow{2}{*}{$\begin{array}{l}\text { TOC* } \\
\text { (wt \%) }\end{array}$} & \multirow[b]{2}{*}{$\mathrm{VR}_{r}(\%)$} & \multicolumn{3}{|c|}{ Langmuir sorption capacity ${ }^{*}$} & \multirow{2}{*}{$\begin{array}{l}\text { Langmuir } \\
\text { pressure } \\
p_{L}(\mathrm{MPa})\end{array}$} & \multirow{2}{*}{$\begin{array}{l}\text { Adsorbed } \\
\text { phase density } \\
\rho_{a d s}\left(\mathrm{~kg} \mathrm{~m}^{-3}\right)\end{array}$} & \multirow{2}{*}{$\begin{array}{l}\text { Desorption } \\
\text { energy } \\
E_{\text {des }}\left(\mathrm{kcal} \mathrm{mol}^{-1}\right)\end{array}$} \\
\hline & & & $n_{L}\left(\mathrm{mmol} \mathrm{g}^{-1}\right)$ & $v_{L}\left(\mathrm{STP} \mathrm{m}^{3} \mathrm{t}^{-1}\right)$ & $v_{L}\left(\operatorname{scf~t~}^{-1}\right)$ & & & \\
\hline $\begin{array}{l}\text { Posidonia } \\
\text { Shale }\end{array}$ & 7.7 & 1.5 & 0.21 & 4.8 & 175 & 8.95 & 423 & 3.24 \\
\hline Wealden & 7.1 & 2.2 & 0.33 & 7.5 & 275 & 17.3 & 421 & 2.27 \\
\hline
\end{tabular}

${ }^{*}$ PeTroMod ${ }^{\circledR}$ input parameter; STP $=273.2 \mathrm{~K}$ and $0.1 \mathrm{MPa}$; data on Posidonia Shale from Gasparik et al. (2014).

(change in Langmuir pressure $p_{L}$ with temperature) with respect to an arbitrarily chosen reference temperature $T_{0}$ (in this case $T_{0}=65^{\circ} \mathrm{C}$ ) and was obtained from sorption isotherms measured over a wide range of temperatures $\left(38-150^{\circ} \mathrm{C}\right)$.

\section{Salt movement}

Due to the presence of salt diapirs and further halokinetic structures in the study area and their importance concerning, e.g. petroleum entrapment, sealing capacity, overpressure generation below the salt, heat conductivity and respective influence on rock maturation in the vicinity, it was of utmost importance to model the geometrical evolution of halokinetic salt diapirism. For this, PETroMoD ${ }^{\circledR}$ provides two basic approaches or primary tools respectively: 'Salt Piercing' and 'Salt Movement'. 'Salt Piercing' substitutes parts of other layers which must not necessarily be connected to salt layers by assigning a salt facies in the geometrical frame of the present-day salt body and at suitable time steps in order to mimic salt movement. 'Salt Movement' changes the geometry of the salt layer, while the layer volume remains constant, meaning that the salt layer moves through other layer over time, directly influencing the model geometry. This, however, often results in distortions, which have to be manually fixed. Here, the 'Salt Movement' approach has been chosen, enabling sediment load-driven linear salt thickness interpolation through time. In addition, an assemblage of 13 palaeothickness maps defining the lateral salt thickness distribution at certain points of time has been applied in order to correct palaeo-geometries based on the interpolation and to consider the different timing of salt movement in the study area.

\section{Heat flow analysis}

As a prerequisite for the determination of geochemical reaction rates, the heat flow analysis aims to determine the temperatures in the basin. For this, heat convection and conduction as well as radiogenic heat production need to be considered and the thermal boundary conditions need to be defined (Hantschel \& Kauerauf, 2009). In order to calculate the temperature gradient and resulting heat flow within a basin, information on the thermal conductivity of the basin infill and the top and base thermal boundary conditions are needed. Basal heat flow is related to processes such as crustal heat production, crustal thinning/mantle upwelling or volcanic activity. The sediment-water interface temperature (SWIT) at the top of the basin is calculated based on the palaeo water depth and palaeo latitude. Finally, radiogenic heat production of the basin infill itself is calculated. This process has often been neglected in the past and hence former studies often overestimated basal heat flow.

\section{Sediment-mater interface temperature + Paleo water depth}

The evolution of the SWIT used for the model was defined using the latitude dependent standard model from PetroMod ${ }^{\circledR}$ based on Wygrala (1989) in correlation with palaeo water depth data based on and modified from van Adrichem Boogaert \& Kouwe (1993), Kockel (2002), Miller et al. (2005) and Littke et al. (2008).

Palaeo water depth does not only influence the interface temperature, but is also important for compaction and pressure implications. Palaeo water depths assigned to the model, however, do not exceed $200 \mathrm{~m}$ and therefore, in comparison to the much larger burial depths due to depositional loading, play only an inferior role to the compaction of rock strata.

\section{Basal heat flow}

In this study, both classical semi-static McKenzie approach (Scenario 2; Fig. 4; McKenzie, 1978) based on and modified from former studies (Petmecky et al., 1999; Senglaub et al., 2005, 2006; Bruns et al., 2013) and the (multi-)1D probabilistic tectonic heat flow modelling approach (Scenario 1; Fig. 5) presented in van Wees et al. (2009) have been applied to the study area. Scenario 2, following the classical heat flow calculations as presented in McKenzie (1978), displays typically elevated heat flow responses during rifting events.

In contrast, the heat flow model presented in van Wees et al. (2009) also incorporates effects of sedimentation and erosion as well as transient effects of surface temperature and radiogenic heat production. It comprises a variety of tectonic scenarios including McKenzie and twolayered stretching/mantle upwelling and is capable of backstripping burial histories, calibrated to palaeo and present-day temperature data. To model the basal and surface heat flow, a simulation is performed for multi-1D synthetic wells which have been constructed from the 


\section{B. Bruns et al.}

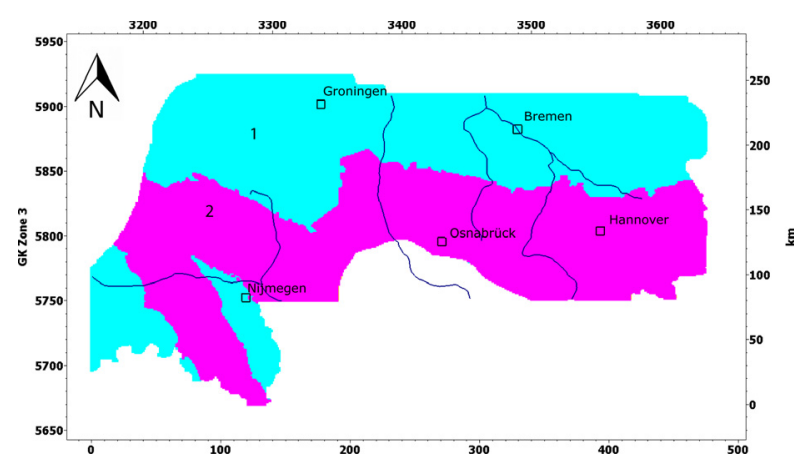

Fig. 4. Heat flow assignment map of scenario 2. Heat flow trends have been presented in Bruns et al. (2013): Area $1 \hat{=} \mathrm{HF}$ Plot: Pompeckj Block, Area 2 今 HF Plot: Lower Saxony Basin. Both heat flow trends incorporate early Permian rift-related peaks of $80-90 \mathrm{~mW} \mathrm{~m}^{-2}$. In Area 2, an additional Late Jurassic rift-related peak of $85 \mathrm{~mW} \mathrm{~m}^{-2}$ was included.

correlated joint model. In this study, a well spacing of ca. $4 \mathrm{~km}$ has been used, resulting in over 4000 synthetic wells. For each of these wells, the backstripped tectonic subsidence is forward modelled with a McKenzie stretching model. The forward modelled lithosphere deformation of the synthetic wells can be depicted in crustal stretching maps (Fig. 6). From these maps, we can derive the spatial and temporal variation in deformation as linked to orientation of the stress tensor.

The crustal stretching factors used as basis for crustal thinning and heat flow implications of a rift model, however, neglect the effects of sediment infill and change in heat production in the crust. As proposed by van Wees et al. (2009), continental heat flow is very sensitive to sedimentation rates during tectonic processes. As a consequence, the typical heat flow response during a rifting phase is decreasing of heat flow because of rapid sedimentation. Heat flow is most strongly elevated during rapid inversion, due to removal and exhumation of relatively hot rocks close to the surface. These heat flow responses are very well visible when plotting the heat flow at the end of a rapid subsidence phase (Fig. 5; e.g. at 309, 89 Ma).

In order to test the sensitivity of modelled erosional thickness which is dependent on basal heat flow during time of deepest burial, these two basal heat flow scenarios have been applied to the $3 \mathrm{D}$ model. The exemplary heat flow trends, representing the two scenarios, as illustrated in Fig. 7, differ significantly. At time of deepest burial prior to the Upper Cretaceous uplift $(89 \mathrm{Ma})$, the basal heat flow can differ by up to $17 \mathrm{~mW} \mathrm{~m}^{-2}$, e.g. in the Lower Saxony Basin, strongly influencing the amount of palaeo burial depth needed to achieve a match with available palaeo-temperature calibration data.

\section{Calibration data}

A large amount of palaeo- and present-day temperature data could be utilized to calibrate the thermal evolution of the sedimentary succession. The dataset consists of vitrinite reflectance $\left(\mathrm{VR}_{r}\right)$ data from outcrops, mines and well cores including own measurements and internal data (mainly based on numerous unpublished bachelor and master theses at RWTH Aachen University), published data (Hecht et al., 1962; Bartenstein et al., 1971; Teichmüller et al., 1979; Altebaeumer, 1982; Teichmüller \& Teichmüller, 1985; Schwarzkopf, 1987; Littke et al., 1988, 1998; Leischner et al., 1993; Leischner, 1994; Büker et al., 1995; Neunzert et al., 1996; Petmecky, 1998; Senglaub et al., 2006; Schwarzer \& Littke, 2007; Blumenstein et al., 2008; Nelskamp et al., 2008; Uffmann et al., 2010), TNO (Dutch Organization for Applied Scientific Research) data and the VIDABA (vitrinite database of the Federal Institute for Geosciences and Natural Resources, BGR) as well as downhole temperature (DHT) data from internal data and partly provided by ExxonMobil (Hannover, Germany). In total, calibration data at 731 locations in the study area was available, covering a stratigraphic interval from the Pennsylvanian to the Tertiary. This dataset has been quality-checked and categorized (Table 5, Fig. 8): The most reliable category (I) consists of $\mathrm{VR}_{r}$ profiles covering deep wells and including Carboniferous samples containing coals or dispersed coaly material. Also, wells with both $\mathrm{VR}_{r}$ and DHT profiles are listed here. The second category (II) includes isolated Carboniferous samples or $\mathrm{VR}_{r}$ profiles excluding the Carboniferous. The third category (III) represents data with only few values excluding the Carboniferous, and the fourth and lowest quality category (IV) consists of only one single non-Carboniferous value. An additional category $(\mathrm{V})$ has been implemented to account for locations with only DHT data available. In general, vitrinite reflectance measurements on coals are more reliable and show a much smaller scatter than those on dispersed coaly particles (Scheidt \& Littke, 1989). This, however, does not mean that measurements on sediments other than coals are of less quality. Thus, despite the fractionation into different quality categories all available data was initially utilized for the calibration process. Only, if data of neighbouring wells or the locally observed lateral maturity trend, respectively, would show discrepancies, further analysis was performed. If maturity shifts between neighbouring wells, e.g. due to fault bounded block separation, could be discarded as explanation, off-limit data was excluded from the calibration process.

It is possible to calculate and predict vitrinite reflectance values by the modelling software through determination of the timing and magnitude of maximum temperatures. The prediction of maturation represented by vitrinite reflectance is based on temperature sensitive Arrhenius type reaction rates and simple conversion equations (Hantschel \& Kauerauf, 2009) so that the temperatures (based on the defined thermal boundary conditions and burial depths) and respective reflectance data can be compared to the measured calibration data. 

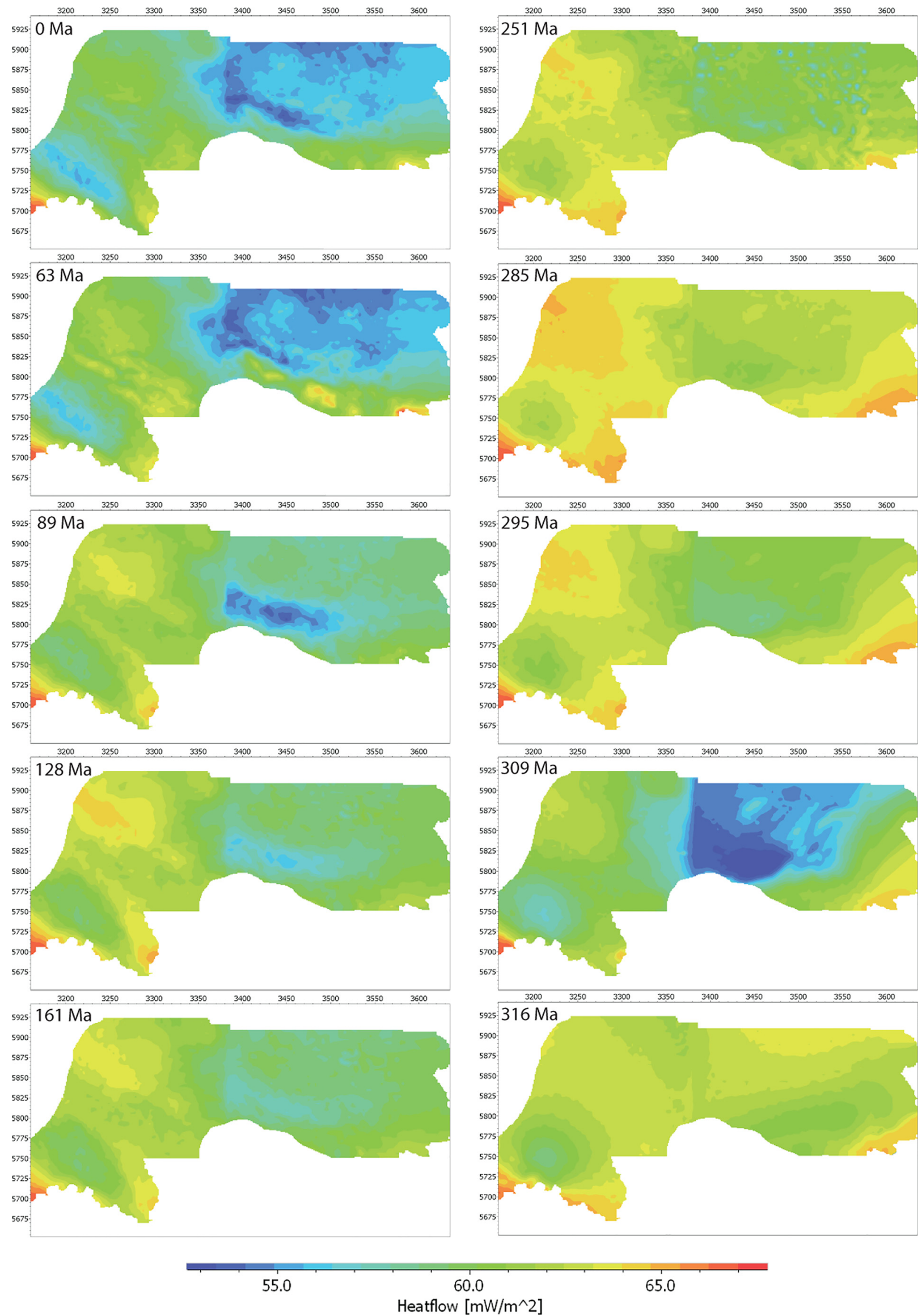

Fig. 5. Basal heat flow maps (scenario 1) based on the approach presented in van Wees et al. (2009). 

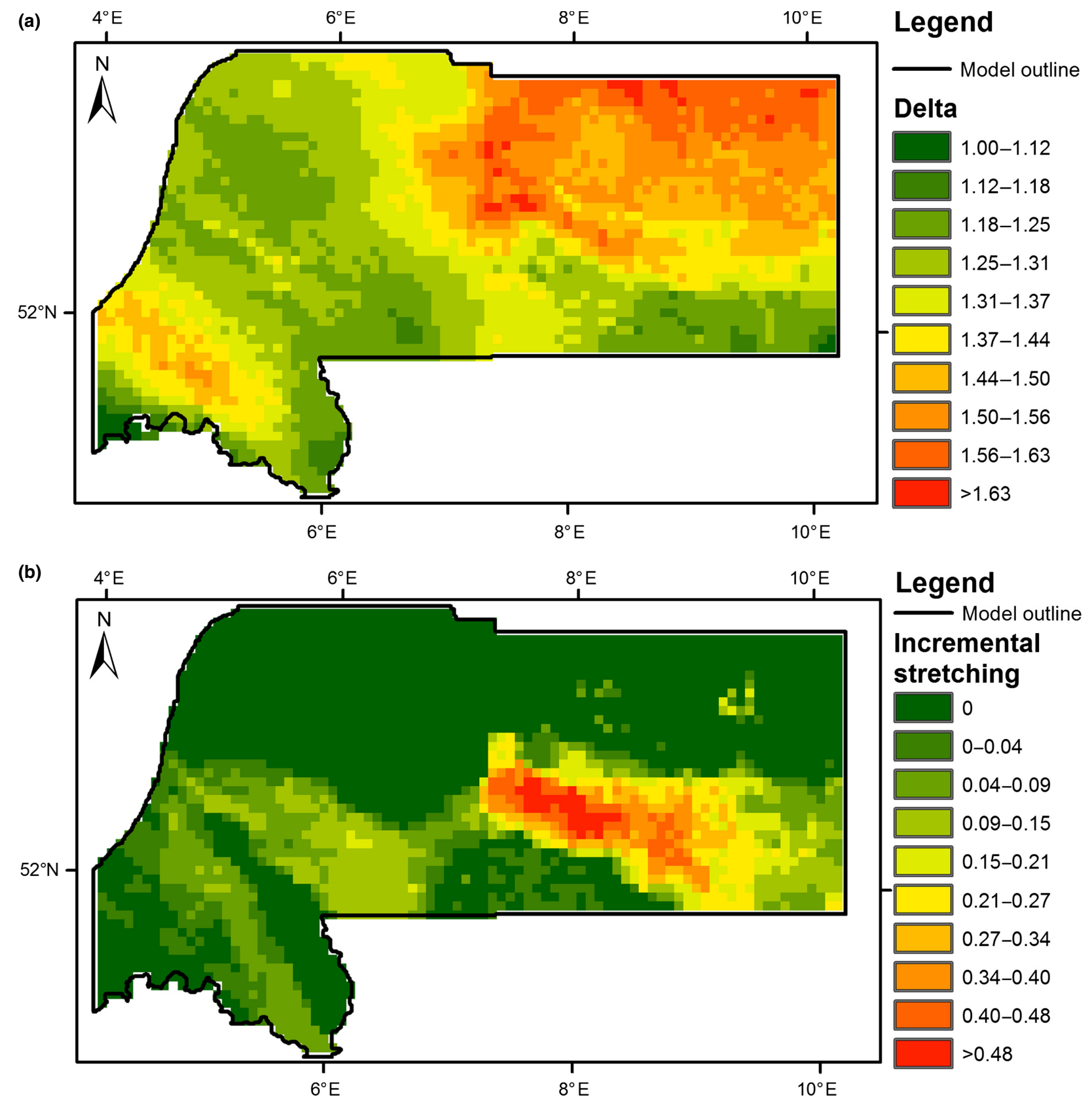

Fig. 6. Top: Total crustal stretching map. Note the gradual increase of cumulative stretching towards the north-east (in particular for the Pompeckj Basin). Bottom: Incremental stretching for the Upper Cretaceous inversion.

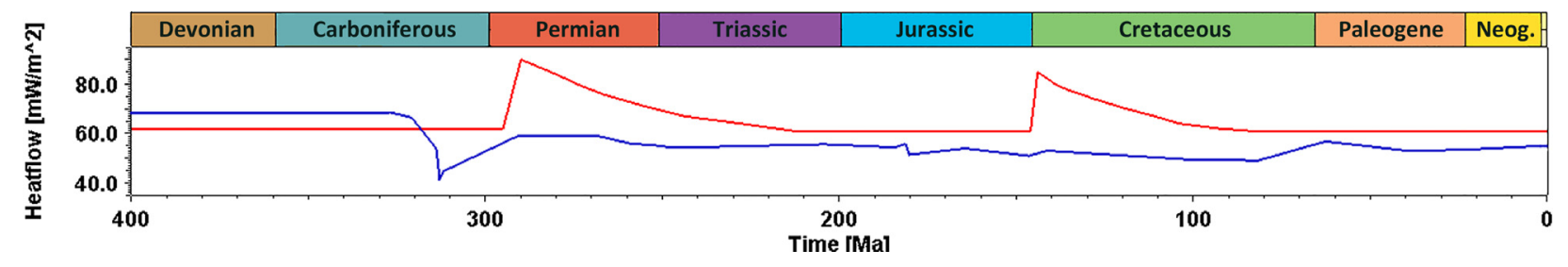

Fig. 7. Exemplary heat flow trends extracted from the central Lower Saxony Basin. Trends taken from the different heat flow scenarios 1 (blue) and 2 (red).

\section{Erosion}

In accordance with the tectonic evolution of $\mathrm{NW}$ Europe, three major uplift/erosion events have been identified in the study area and were included in the modelling by erosion maps. The compilation of these erosion maps followed the multi-1D approach described in Bruns et al. (2013) (Fig. 9): 1D models at 731 
Table 5. Summary and quality categorization of the calibration dataset

\begin{tabular}{llcl}
\hline Category & Locations & $\%$ & Color \\
\hline I & 112 & 15.32 & \\
II & 156 & 21.34 & \\
III & 104 & 14.22 & \\
IV & 319 & 43.64 & \\
V & 40 & 5.48 & \\
Total & 731 & 100 & \\
\hline
\end{tabular}

locations were extracted from the 3D model. The erosion amounts and palaeo burial depths, respectively, were modelled taking the different basal heat flow scenarios as basis. The erosion amounts were constrained and calibrated by vitrinite reflectance and DHT data and obtained by means of 1D temperature and pressure simulations. These modelled erosion amounts were manually transferred into erosion maps and used as data points for finalizing the maps by inverse distance interpolation. The quality of the resulting erosion maps, hence, highly depends on the lateral distribution density of the calibration data itself. In the area of the Netherlands, only a comparably small amount of locations with calibration data was made available. The compiled erosion maps might therefore show qualitative deficits concerning the interpolation of erosional amounts in the Dutch area in comparison to Germany where the data density is much higher. In order to finalize these erosion maps they were used in $3 \mathrm{D}$ simulations. As maturity calculations can differ between $3 \mathrm{D}$ and $1 \mathrm{D}$ simulations despite being based on the same input a quality check of the calculated maturities based on a 3D temperature and pressure simulation approach needed to be performed (Bruns et al., 2013). The amounts of eroded overburden and respective erosion maps (based on 1D simulation results) were therefore, if needed, slightly refined to match the available calibration data.

\section{RESULTS}

\section{Burial and erosion}

The Variscan (Asturian) tectonic phase induced uplift throughout most parts of the study area leading to erosion rates of up to $760 \mathrm{~m} \mathrm{Ma}^{-1}$ and erosional thicknesses of up to $3800 \mathrm{~m}$ of Westphalian deposits in the Münsterland Basin as well as northeastern future Lower Saxony Basin and up to $2400 \mathrm{~m}$ with rates up to $480 \mathrm{~m} \mathrm{Ma}^{-1}$ in the northern onshore Netherlands during the Upper Carboniferous/Lower Permian (Fig. 10). Van Wees et al. (2000) stated that a combination of wrench-related lithospheric deformation, thermal erosion of the mantle lithosphere, and magmatic inflation of the lithosphere during the $\mathrm{Au}-$ tunian caused volcanic activity and uplift in the Netherlands. De Jager \& Geluk (2007) added that Stephanian and Westphalian deposits were subject to a maximum amount of erosion of $c a$. $1800 \mathrm{~m}$ of Westphalian sediments. Our erosion map is based on maps of initial (Drozdzewski \& Wrede, 1994) and present-day thickness distribution of the Westphalian (Gerling et al., 1999b). The erosion map was compiled by subtracting the present-day Westphalian thickness from the initial

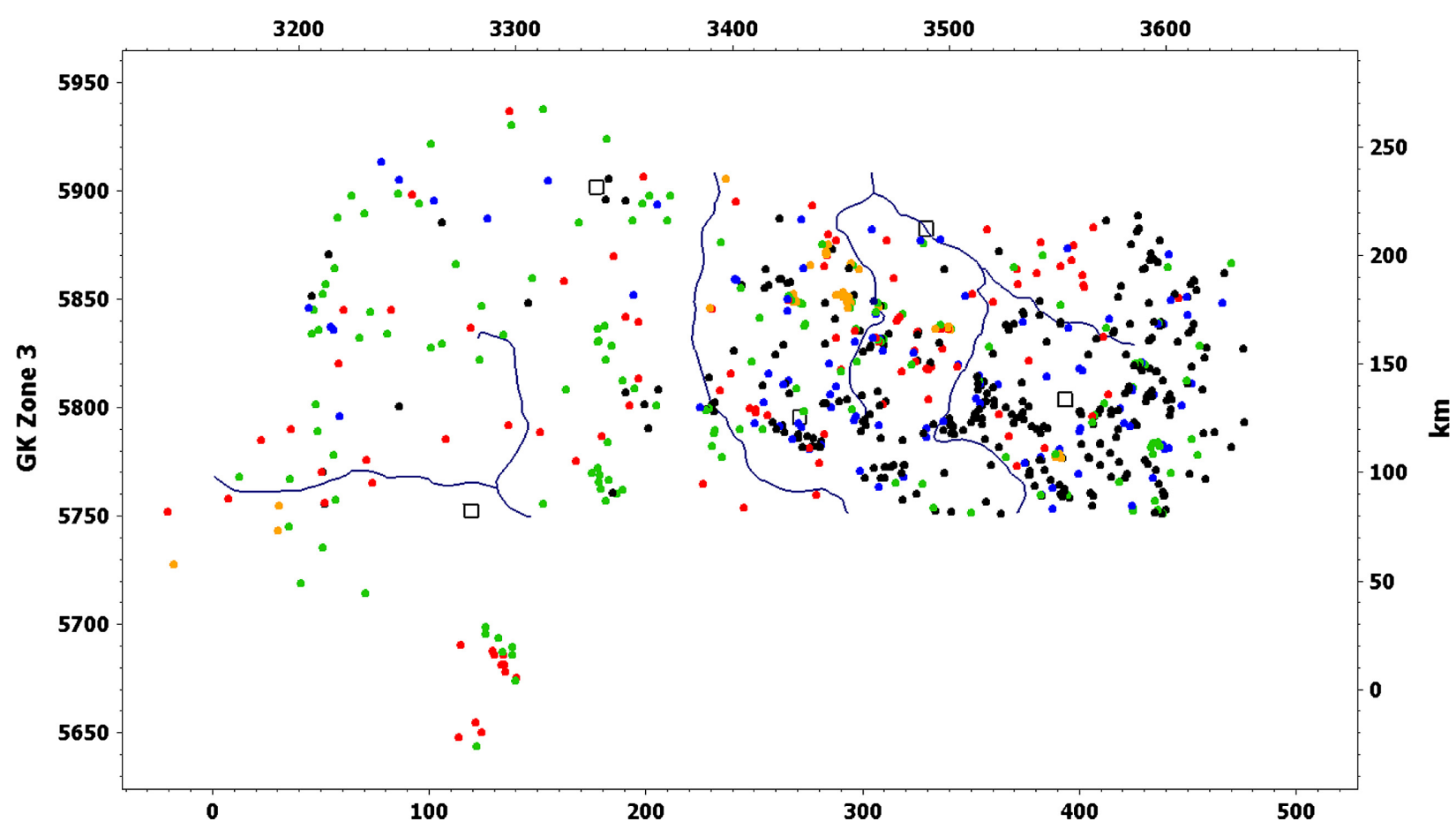

Fig. 8. Locations with available palaeo and present-day temperature calibration data. Colours represent different quality categories (see Table 5). 


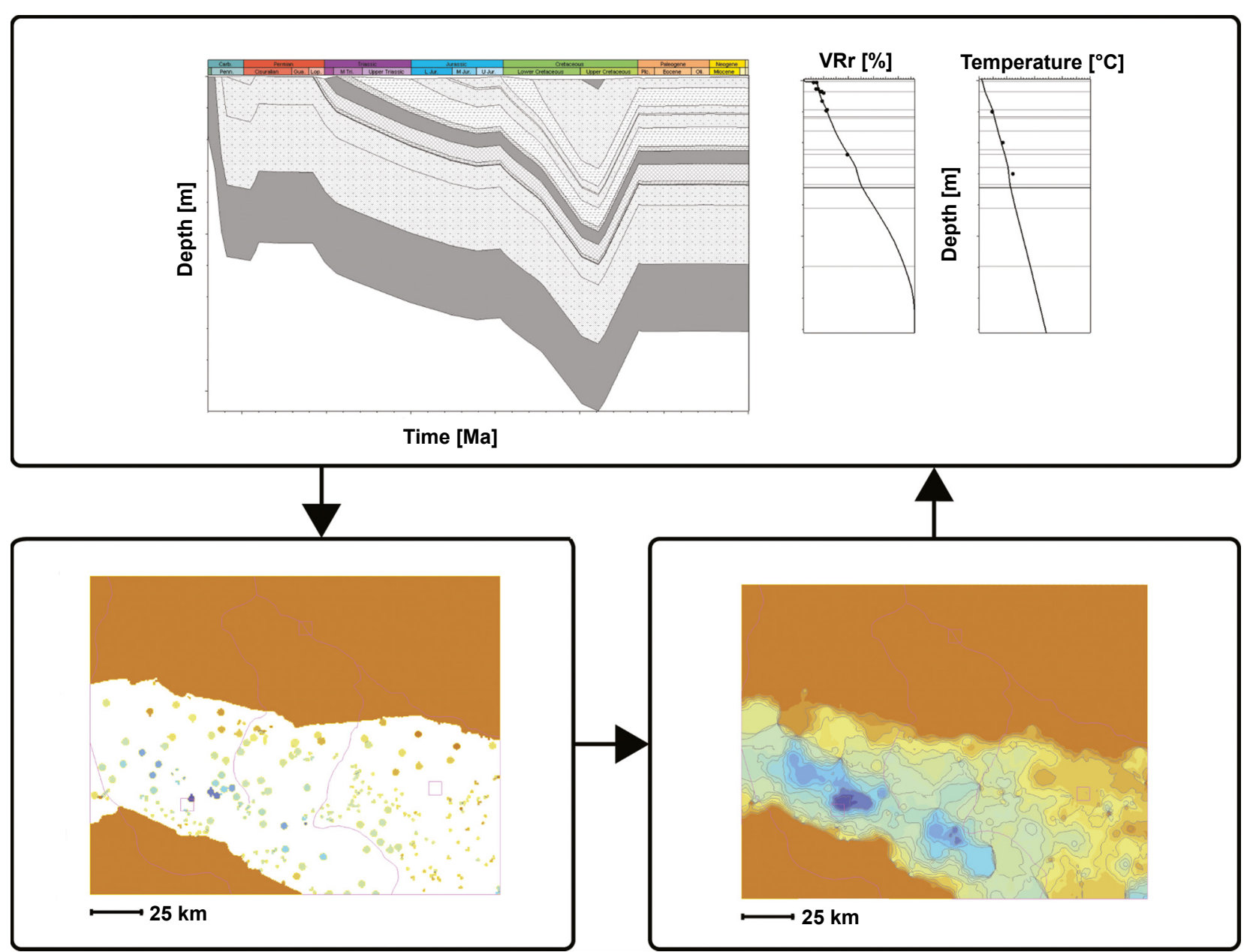

Fig. 9. Workflow chart of the erosion map compilation. 1D basin models extracted from the 3D model were used to model eroded thicknesses (upper left). Data were plotted in multi-1D maps (lower left). Erosion maps were compiled by interpolation of the multi1D maps (lower right). A final 3D model was created, in which minor refinements of eroded thicknesses were performed until an optimal calibration (upper right) was achieved (modified from Bruns et al., 2013).

thickness map. In areas where at present-day Westphalian $\mathrm{D}$ is still present, no or little erosion took place (western Lower Saxony Basin).

During the latest Jurassic parts of the (from East to West) Pompeckj Basin, Groningen Platform, Lauwerszee Trough, Friesland Platform, Vlieland Basin, Texel-Ijsselmeer High and Noord-Holland Platform in the North of the study area as well as the (from East to West) Krefeld High, Peel-Maasbommel Complex and Zeeland High in the South were uplifted during the Kimmerian tectonic phase. On average, $1100 \mathrm{~m}$ (Scenario 1) and $800 \mathrm{~m}$ (Scenario 2) with maxima of $4500 \mathrm{~m}$ (Scenario 1) and $4200 \mathrm{~m}$ (Scenario 2) of basin infill has been eroded. The erosion affected a large stratigraphic column, locally even the Carboniferous. Modelled uplift rates vary but can reach up to $300 \mathrm{~m} \mathrm{Ma}^{-1}$ in areas where strongest uplift and erosion is observed (Fig. 11a). This erosion phase mainly affected structural highs or platforms.

The last major erosion phase (Subhercynian) that affected the study area is related to the Alpine Orogeny during the Upper Cretaceous to Paleogene. This erosion phase mainly influenced the basins and caused severe uplift and erosion. Inversion and modelled erosion amounts have been strongest during this phase removing large amounts of Cretaceous to Triassic and even Paleozoic deposits in the (from East to West) southern part of the Gifhorn Trough, Lower Saxony Basin, Central and West Netherlands basins. Maximum uplift rates of up to $370 \mathrm{~m} \mathrm{Ma}^{-1}$ induced erosion of up to $8950 \mathrm{~m}$ (Scenario 1) and $6700 \mathrm{~m}$ (Scenario 2) in the Lower Saxony Basin near Osnabrück. On average, $1920 \mathrm{~m}$ (Scenario 1) and $1535 \mathrm{~m}$ (Scenario 2) of the initial layer thickness has been removed during this period (Fig. 11b, c). Burial in the southwestern part of the West Netherlands Basin is deepest at present day; only the northeastern flank and the Central Netherlands Basin have been influenced by moderate uplift during the Upper Cretaceous. Observed present-day maturities in the study area which are due to increased palaeo burial depth differ significantly between the basins in Germany and the Netherlands. Former burial depths in the Dutch basins were much lower than in parts of the Lower Saxony Basin. 


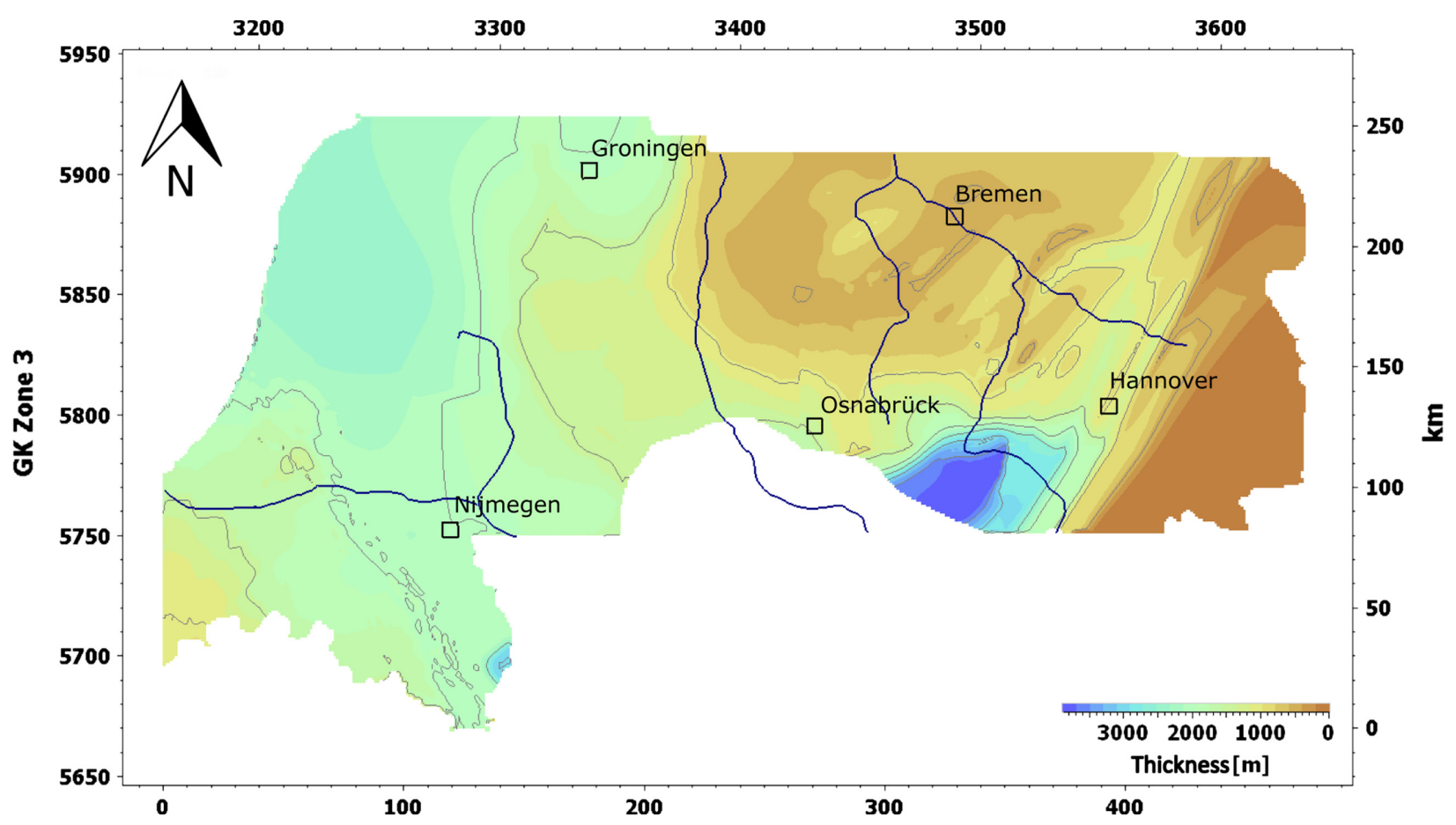

Fig. 10. Total amount of eroded overburden removed during the Variscan/Asturian (Upper Carboniferous) inversion.

\section{Maturity evolution}

\section{Posidonia Shale}

At the Jurassic/Cretaceous boundary the top of the Posidonia Shale had been buried to average depths of 2000$3000 \mathrm{~m}(\mathrm{max} .3600 \mathrm{~m})$ in the Lower Saxony Basin centre, $1000-1700 \mathrm{~m}(\max .2700 \mathrm{~m})$ in the Gifhorn Trough, $500 \mathrm{~m}$ in the Pompeckj Basin (max. $1200 \mathrm{~m}$ ) and 1000$1700 \mathrm{~m}(\max .2600 \mathrm{~m})$ in the West Netherlands Basin. Areas affected by Kimmerian uplift (see Fig. 11a) had formerly been buried to maximum depths of $4500 \mathrm{~m}$ (Scenario 1) and $4000 \mathrm{~m}$ (Scenario 2) in the Pompeckj Basin, $2850 \mathrm{~m}$ (Scenario 1) and $2650 \mathrm{~m}$ (Scenario 2) in the Friesland Platform as well as $1950 \mathrm{~m}$ (Scenario 1) and $1600 \mathrm{~m}$ (Scenario 2 ) in the Peel-Maasbommel Complex and Krefeld High.

Lower Cretaceous deposition increased the burial depth of the Posidonia Shale in the Lower Saxony Basin significantly. During the Upper Cretaceous the end of sedimentation ( $89 \mathrm{Ma}$ ) was characterized by greatest burial depths as deep as $10000 \mathrm{~m}$ (Scenario 1) and $7800 \mathrm{~m}$ (Scenario 2) resulting in temperatures of up to $330^{\circ} \mathrm{C}$. Maturities in some parts of the Lower Saxony Basin depocentre reached the overmature state partly exceeding $4.66 \% \mathrm{VR}_{r}$ [the kinetic of Sweeney \& Burnham (1990), used for maturity calculation in this model, allows calculations only up to $4.66 \% \mathrm{VR}_{r}$ ]. The average maturation in the basin centre reached the dry gas stage $\left(>2.3 \% \mathrm{VR}_{r}\right)$ whereas the basin margin maturities remained in the oil window. Maturation of the Pompeckj Basin also progressed, especially in the rim basins of salt diapirs and salt walls, reaching the early to main oil generation stage (Fig. 12). In the eastern Gifhorn Trough, burial reached maximum depths of up to $4400 \mathrm{~m}$ (Scenario 1) and $3800 \mathrm{~m}$ (Scenario 2). Temperatures ranged between 80 and $120^{\circ} \mathrm{C}$ but were locally higher reaching up to $180^{\circ} \mathrm{C}$, resulting in maturities within the oil generation window. At small confined spots often associated with salt structures maturities increased up to the wet gas stage (1.3$2.3 \% \mathrm{VR}_{r}$ ).

Since then maturities in the Lower Saxony Basin did not increase. The Subhercynian inversion induced uplift and erosion of the Lower Saxony Basin removing up to $8950 \mathrm{~m}$ (Scenario 1) and $6800 \mathrm{~m}$ (Scenario 2) of basin infill. Today, the top of the Posidonia Shale can be found at depths between 0 and $3600 \mathrm{~m}$ with deepest locations in the northwestern West Netherlands Basin, northern Lower Saxony Basin and northeastern Pompeckj Basin. During uplift of the Lower Saxony Basin the deposition in the Pompeckj Basin and the northern part of the Gifhorn Trough proceeded leading to maximum burial depths of up to $3600 \mathrm{~m}$ in the Pompeckj Basin and $3000 \mathrm{~m}$ in the Gifhorn Trough. Thus, more areas in the Pompeckj Basin and Gifhorn Trough have nowadays reached the oil generation stage (Fig. 12).

Prior to the Subhercynian erosion during the Upper Cretaceous the end of sedimentation in the Netherlands was only partly characterized by greatest burial depths. Average burial depths in the West Netherlands Basin equalled $2600 \mathrm{~m}$ in the centre and $1600 \mathrm{~m}$ at the basin flanks. The Central Netherlands Basin shows burial depths of $1800 \mathrm{~m}$ on average. Temperatures ranged between 75 and $120^{\circ} \mathrm{C}$ resulting in maturities of $0.4-1.2 \%$ $\mathrm{VR}_{r}$; thus, large parts of the basins reached the oil generation stage (Fig. 12). 


\section{B. Bruns et al.}
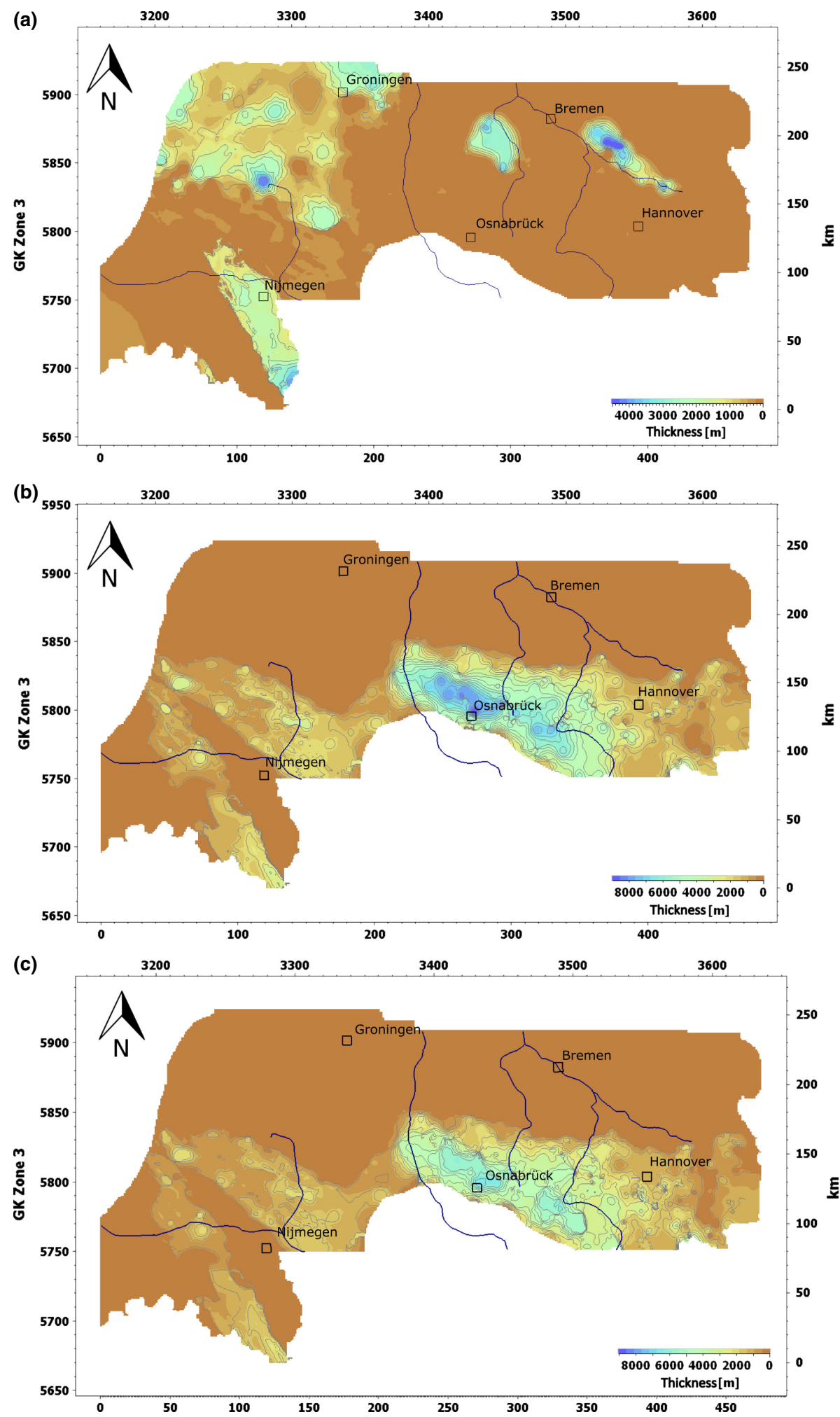

Fig. 11. Scenario 1: Total amount of eroded overburden removed during the Kimmerian (Upper Jurassic) inversion (a), Scenario 1: Total amount of eroded overburden removed during the Subhercynian (Upper Cretaceous) inversion (b), Scenario 2: Total amount of eroded overburden removed during the Subhercynian (Upper Cretaceous) inversion (c).

The Subhercynian erosion removed up to $2900 \mathrm{~m}$ (Scenario 1) and $2200 \mathrm{~m}$ (Scenario 2) of basin infill and most of the Posidonia Shale in the area of the Central Netherlands Basin. Therefore, at present day the Posido- nia Shale in the Netherlands is only widespread in the West Netherlands Basin, where erosion was not as distinct. Burial, especially in the southwestern part of the West Netherlands Basin, continued until present day. 
Burial depths of up to $3600 \mathrm{~m}$ result in temperatures of up to $140^{\circ} \mathrm{C}$ and maturities up to the late oil-early gas generation stage (1.3\% VR $r$ ) (Fig. 12).

\section{Wealden/Coevorden formation}

During the Upper Cretaceous prior to the main uplift phase the end of sedimentation in the Lower Saxony Basin $(89 \mathrm{Ma}$ ) was characterized by greatest burial depths of up to $7900 \mathrm{~m}$ (Scenario 1) and $5800 \mathrm{~m}$ (Scenario 2) resulting in temperatures of up to $260^{\circ} \mathrm{C}$. Maturities in some confined parts of the Lower Saxony Basin depocentre reached up to $3.7 \% \mathrm{VR}_{r}$; the average maturation in the basin centre reached the dry gas stage $\left(>2.3 \% \mathrm{VR}_{r}\right)$ whereas the basin margin maturities remained in the oil window (Fig. 13). The Pompeckj Basin and eastern part of the Gifhorn Trough mainly remained immature. In the western Gifhorn Trough, the burial reached maximum depths up to $3700 \mathrm{~m}$ (Scenario 1) and $2300 \mathrm{~m}$ (Scenario 2). Temperatures ranged between 50 and $100^{\circ} \mathrm{C}$ but locally reached up to $140^{\circ} \mathrm{C}$, resulting in maturities of $0.6-0.9 \% \mathrm{VR}_{r}$ within the oil generation window.

The top of the Wealden at present day can be found at depths of up to $2700 \mathrm{~m}$. In the Lower Saxony Basin the Wealden has been uplifted and its top is now only at a few hundred metres depth or even at the surface. Deep-seated areas can be found in the Pompeckj Basin, Gifhorn Trough and the Netherlands where burial continued until today or uplift was not that distinct. Due to deep burial in the Lower Saxony Basin centre, the gas production stage was reached with highest maturities exceeding $3 \% \mathrm{VR}_{r}$. The northern and northeastern boundaries of the Lower Saxony Basin exhibit lower maturities within the oil production window due to lower burial depth. The Wealden-equivalent Coevorden Formation in the Netherlands still remained immature (Fig. 13).

\section{Gas sorption}

Using the experimentally derived Langmuir sorption parameters for Posidonia Shale samples from the Hils Syncline, NW-Germany (Gasparik et al., 2014), the evolution of sorption capacity and sorbed gas contents based on the calibrated burial and thermal history has been simulated. At present day, the Posidonia Shale exhibits a varying lateral distribution of sorption capacity due to the differentiated burial history. However, in the central part of the Lower Saxony Basin, comparably low bulk adsorption capacities of about $1.3^{*} 10^{6}$ tons (note that bulk adsorption capacities are given for the total layer thickness within a grid cell size of $1 \mathrm{~km}^{2}$ ) have been predicted, the capacities at the northern and eastern boundaries of the Lower Saxony Basin, Pompeckj Basin and Gifhorn Trough range around $2.5^{*} 10^{6}$ tons. In the West Netherlands Basin and other locally confined spots where the Posidonia Shale in the Netherlands can be found nowadays, capacities range between 1.2 and $2.8 * 10^{6}$ tons (Fig. 14a).
In comparison to the bulk adsorption capacities, the lateral distribution of the sorbed gas content shows a different picture. For the central area of the Lower Saxony Basin, gas contents of up to $82 \mathrm{scf}^{-1} \mathrm{ton}^{-1}$ rock have been calculated. Despite the higher adsorption capacity predicted for the Pompeckj Basin, significant gas contents can only be found in few areas associated with salt structures where thermal maturities have reached the gas generation stage. In the southern part of the Gifhorn Trough and southwestern flank of the West Netherlands Basin, average gas contents of up to $95 \mathrm{scf}^{-1} \mathrm{ton}^{-1}$ rock have been predicted (Fig. 14b, c).

Figure 15 illustrates the present-day adsorption capacity and average gas contents in the Wealden. The observable hard boundary in the east is due to a source to nonsource-rock facies differentiation based on Gerling et al. (1999a). In reality, the adsorption capacity should resemble a gradual transition due to intertwined intersections of shaly and sandy facies. The lateral distribution of bulk adsorption capacity of the Wealden resembles its layer thickness (Fig. 3). Capacities are highest in areas with increased layer thickness and range up to $27 * 10^{6}$ tons. Major gas contents in the Lower Saxony Basin have been calculated for the Ems river area with values up to $26 \mathrm{scf}^{-1} \mathrm{ton}^{-1}$ rock and the Hunte river area with contents up to $45 \mathrm{scf}^{-1} \mathrm{ton}^{-1}$ rock (Fig. 15b, c).

Results show that the burial/inversion scenario 1 generally favours gas sorption in comparison to scenario 2 . Due to deeper burial and lower temperature gradients, higher amounts of gas can be observed in scenario 1 (compare Fig. 11b, c). Deeper burial leads to higher pressures increasing the amount of gas which can be stored in the pore space. Lower temperature gradients increase the sorption capacity. Gas that had been generated and adsorbed until deepest burial has been preserved during uplift as bulk adsorption capacity actually increases during uplift due to gradually decreasing temperatures (see Discussion).

For the Posidonia Shale in the centre of the Lower Saxony Basin and in the northwestern part of the West Netherlands Basin, two representative 1D time plots (Fig. 16) have been extracted from the simulated 3D model. These 1D time plots illustrate the evolution of the burial history and the corresponding changes in temperature, transformation ratio (TR), adsorption capacity, methane generation due to secondary cracking and adsorbed gas contents of the Posidonia Shale. It should be noted here that the different burial histories in individual areas result in a varying filling evolution as well as in a varying gas content and composition. The onset of gas generation took place almost simultaneously in all areas when sufficient temperatures were reached. However, due to a fast and deep burial in the Lower Saxony Basin, the maximum temperatures were reached much earlier $(89 \mathrm{Ma})$ than at the southwestern margin of the West Netherlands Basin (0 Ma). Kerogen conversion in the Lower Saxony Basin, represented by the TR, was already completed between 100 and $95 \mathrm{Ma}$. At present day, the southwestern part of 


\section{B. Bruns et al.}
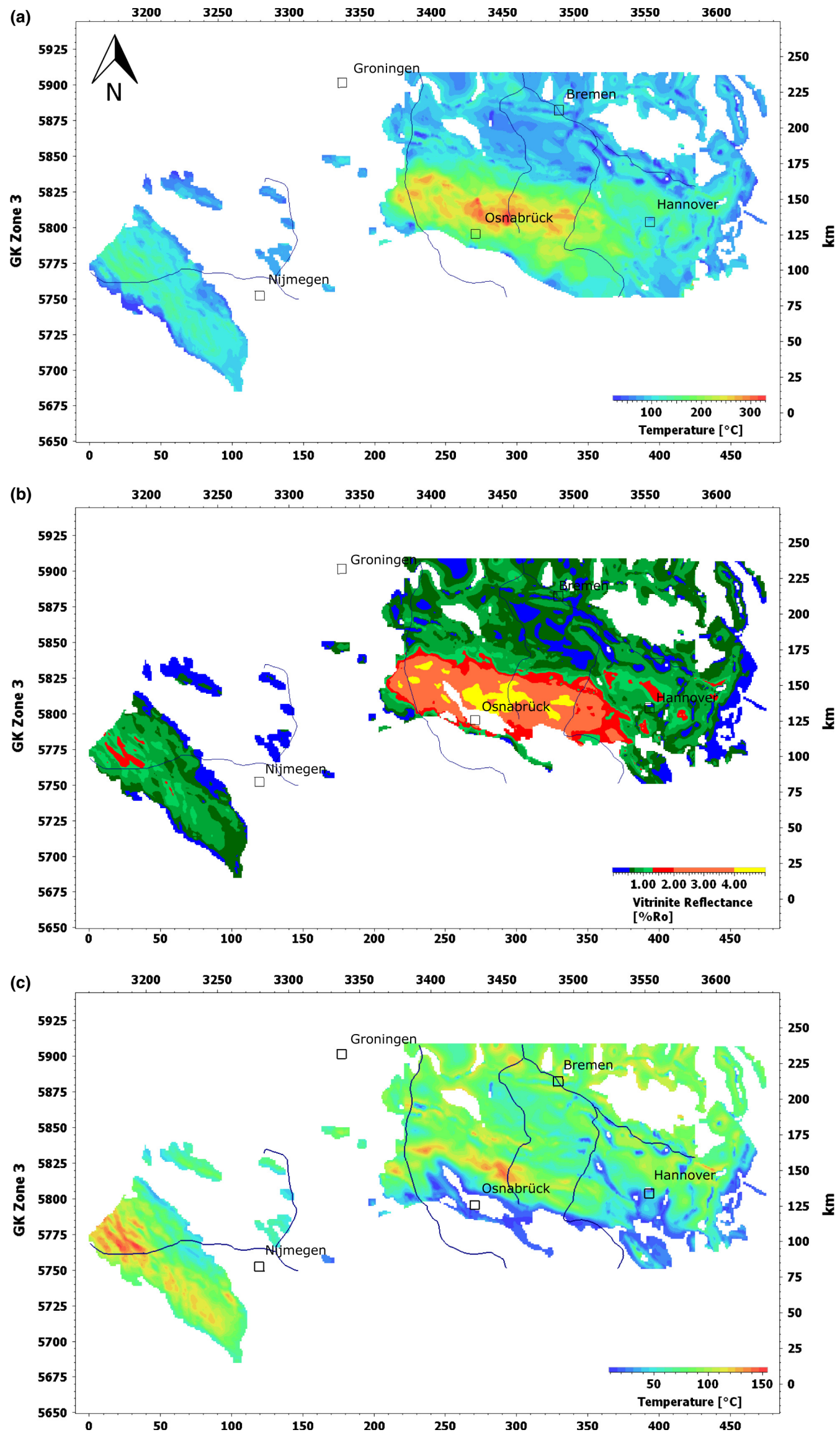

Fig. 12. Temperature during deepest burial at $89 \mathrm{Ma}$ (a), present-day maturity (b) and present-day temperature (c) at the top of the Posidonia Shale. 

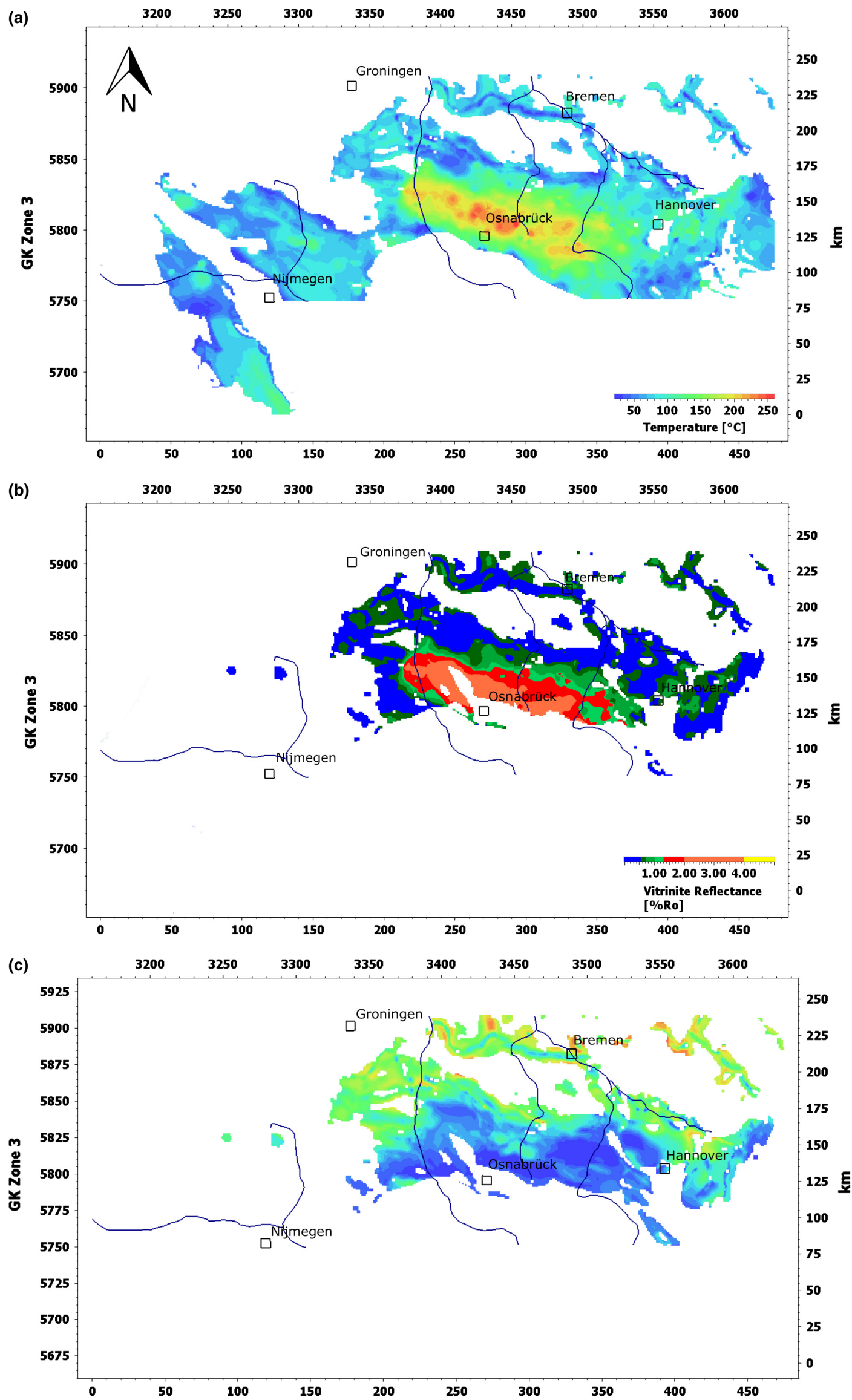

Fig. 13. Temperature during deepest burial at $89 \mathrm{Ma}$ (a), present-day maturity (b) and present-day temperature (c) at the top of the Wealden. 

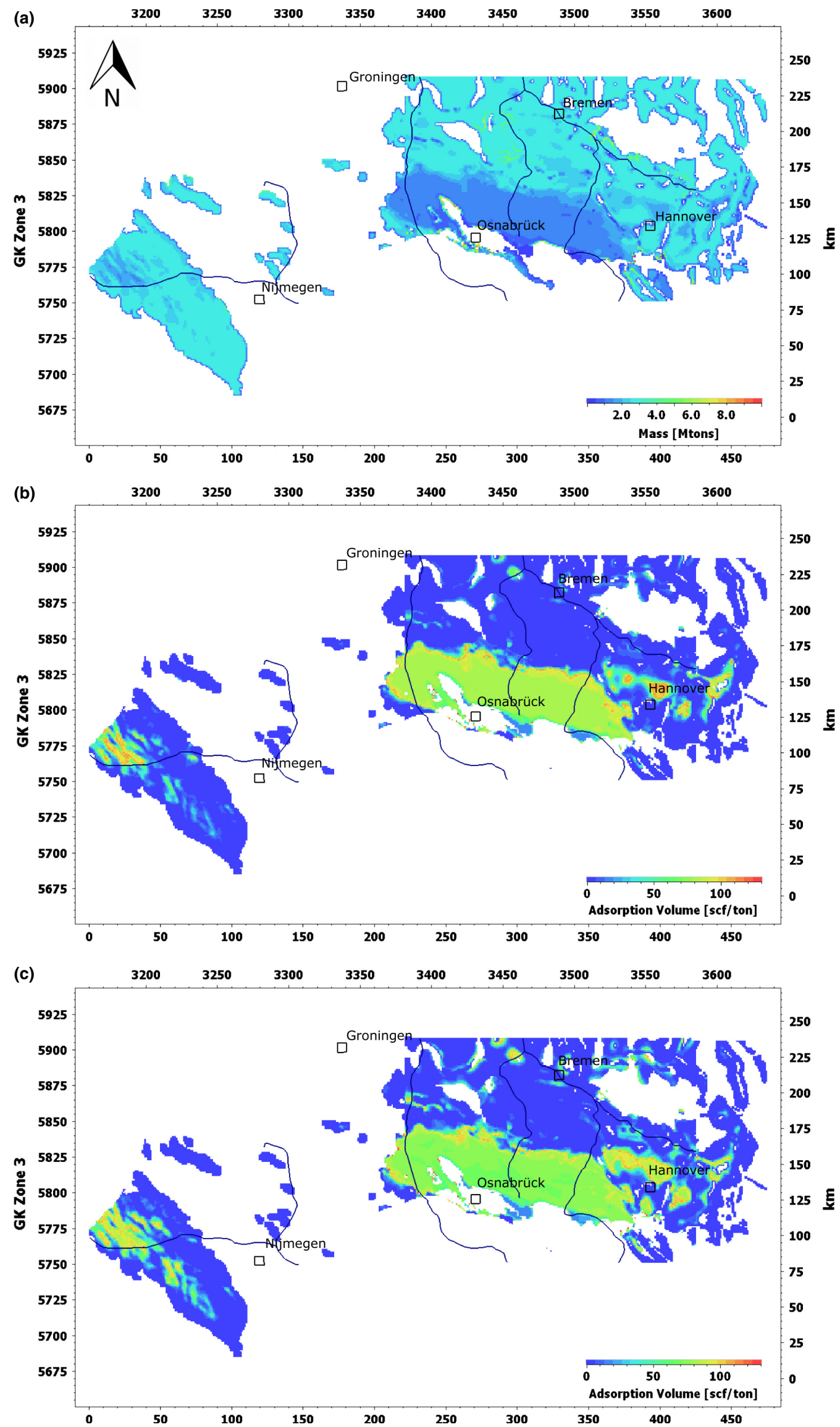

Fig. 14. Present-day total bulk adsorption capacity ( $\mathrm{a} ; 10^{6}$ tons per layer thickness within a grid cell size of $\left.1 \mathrm{~km}^{2}\right)$, and average volume of methane at standard conditions per mass of rock $\left(b=\right.$ Scenario $1 ; \mathrm{c}=$ Scenario 2; scf ton ${ }^{-1}$ rock $)$ of the Posidonia Shale. 
the West Netherlands Basin is at its maximum burial depth. Only the northeastern flank has been influenced by moderate uplift during the Upper Cretaceous. The bulk adsorption capacities in the West Netherlands Basin predicted by the model are increasing up to certain temperature and pressure conditions and decrease thereafter with further burial. On the other hand, since the beginning of uplift in the Lower Saxony Basin, the bulk adsorption capacities remained almost constant until present day. The onset of gas generation is marked by the increase in gas content. It should be noted that microbial gas generation has not been included into the model and cannot be ruled out as an additional contributor.

\section{DISCUSSION AND SENSITIVITY ANALYSIS}

\section{Erosion}

Due to the high amount of modelled erosion during the Upper Cretaceous (Subhercynian) uplift questions may arise whether the respective uplift rates are plausible and whether enough accommodation space in adjacent areas was available. The modelled erosion rates range between 100 and $370 \mathrm{~m} \mathrm{Ma}^{-1}$ and therefore represent a rather moderate uplift scenario which is certainly plausible for a transpressional tectonic regime in combination with a humid climate at that time. Layer thickness maps of the Upper Cretaceous and Paleogene indicate that the general regional transport direction was N-NW-oriented (Fig. 17). A mass balance analysis comparing accumulated Upper Cretaceous and Paleogene deposits with eroded sediment volumes taking into account time of erosion and sedimentation (Figs. 17 and 18) indicates a correlation of increased sedimentation rates in adjacent areas during and after erosion in, e.g. the Lower Saxony Basin as well as between eroded and accumulated volumes. In the study area, about $69900 \mathrm{~km}^{3}$ (Scenario 1) or $58600 \mathrm{~km}^{3}$ (Scenario 2) of eroded deposits were modelled. In comparison, $34600 \mathrm{~km}^{3}$ of Upper Cretaceous and $26400 \mathrm{~km}^{3}$ of Paleogene layer volume can be observed at present day. Although lithological differences (e.g. clastics vs. carbonates) as well as carbonate dissolution, water currents and additional accommodation space further north in the North Sea sector also have to be considered, it is still obvious that there was sufficient accommodation space for the eroded sediment volume.

Assigned lithologies/facies of the eroded deposits also affect calculated temperatures/maturity but this effect is mainly controlled by the differential heat conductivity and only marginally by differential compaction rates. The comparison of pure shale, pure limestone and the original user-defined lithologies for the eroded deposits of, e.g. $2700 \mathrm{~m}$ yields a difference in initial thickness of only $100 \mathrm{~m}$ for shales in comparison to carbonates, therefore not taking significant influence on the burial depth. Instead, the decreased thermal conductivity of a shaly (in contrast to a limestone or sandstone) lithology results in additional heat accumulation and elevated temperatures/ maturity. Figure $19 \mathrm{~d}$ shows this effect for one well. In the modelling runs, only the lithologies of eroded Lower and Upper Cretaceous strata have been replaced resulting in a significant change in temperature and maturity. In reality, the lithologies are constrained by preserved layers e.g. in the Pompeckj Basin just north of the Lower Saxony Basin and/or by palaeogeographic information (e.g. Ziegler, 1990). Nevertheless, the analysis (Fig. 19d) implies that lithologies (petrophysical properties) of now eroded layers lead to major uncertainties in temperature history modelling.

\section{Maturity and thermal calibration}

The presented heat flow and erosion scenarios are based on a thermal calibration utilizing vitrinite reflectance (palaeo-temperature) and DHT data. Hereby, measured and simulated vitrinite reflectance and temperature vs. depth trends are being matched by adjusting the amount of basal heat flow as well as palaeo burial depth and erosion, respectively. The modelled erosion scenarios already present a sensitivity analysis on a basin wide-scale showing their dependency on differing basal heat flow. In order to further illustrate the calibration procedure and the sensitivity of modelling results to changing input data Fig. 19 displays several scenarios developed for the representative well of the Lower Saxony Basin shown in Fig. 18 (top). A best-fit model has been created assuming basal heat flow scenario 2 as displayed in Fig. 7 in combination with an erosion amount of $2700 \mathrm{~m}$ (Scenario 2; Fig. 18). Using basal heat flow scenario 2 with $59 \mathrm{~mW} \mathrm{~m}^{-2}$ at the time of deepest burial different amounts of palaeo burial depth and erosion (ranging between 2300 and $3300 \mathrm{~m}$ ) during the following Subhercynian Inversion were tested (Fig. 19a). In an alternative scenario, leaving the amount of eroded deposits at a constant value of $2700 \mathrm{~m}$, differing assumptions on basal heat flow during time of deepest burial were applied ranging from 68 to $48 \mathrm{~mW} \mathrm{~m}^{-2}$ (Fig. 19b).

The lower thermal boundary is defined by the basal heat flux into the basin. The underlying artificial basement layer with an average thickness of $10000 \mathrm{~m}$ also features a radiogenic matrix heat production of $1 \mu \mathrm{W} \mathrm{m}^{-3}$. Thus, the actual lower thermal boundary of the $3 \mathrm{D}$ model is a combination of the assigned basal heat flow through time and the radiogenic heat production of the basement layer. The basement layer thickness therefore influences the needed amount of basal heat flow and the assigned heat flow trends would exhibit slightly higher values if the basement layer had been excluded. This is shown in Fig. 19e, where simulated vitrinite reflectance trends based on incorporation and exclusion of this basement layer have been compared using the same basal heat flow trend and erosion amount.

The implementation of natural radiogenic heat production of the basin infill itself has shown that a reassessment of former basin modelling studies is generally needed. 

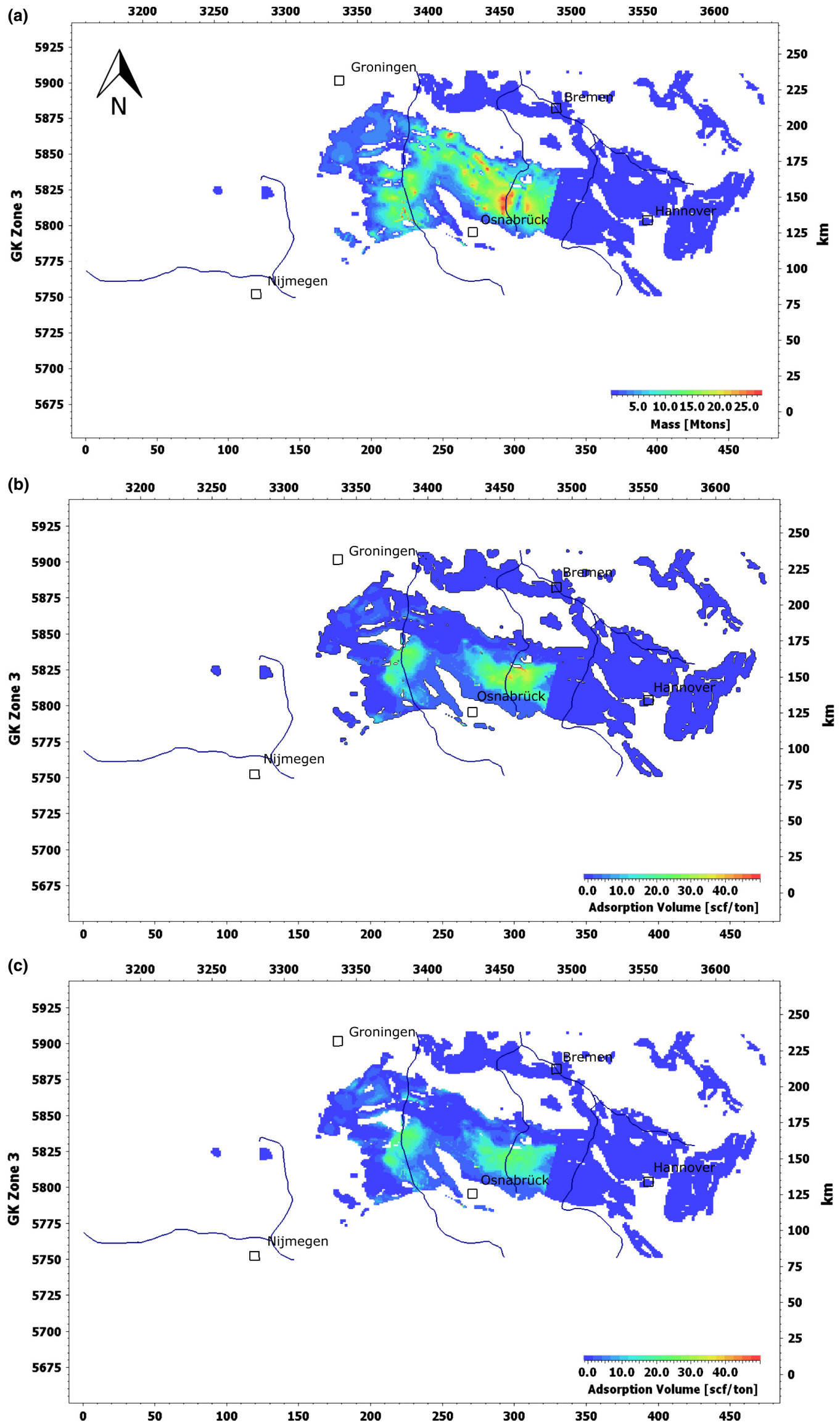

Fig. 15. Present-day total bulk adsorption capacity (a; $10^{6 *}$ tons per layer thickness within a grid cell size of $\left.1 \mathrm{~km}^{2}\right)$ and average volume of methane at standard conditions per mass of rock $\left(b=\right.$ Scenario $1 ; c=$ Scenario $2 ;\left(\operatorname{scf}^{-1}\right.$ ton $^{-1}$ rock) of the Wealden. 

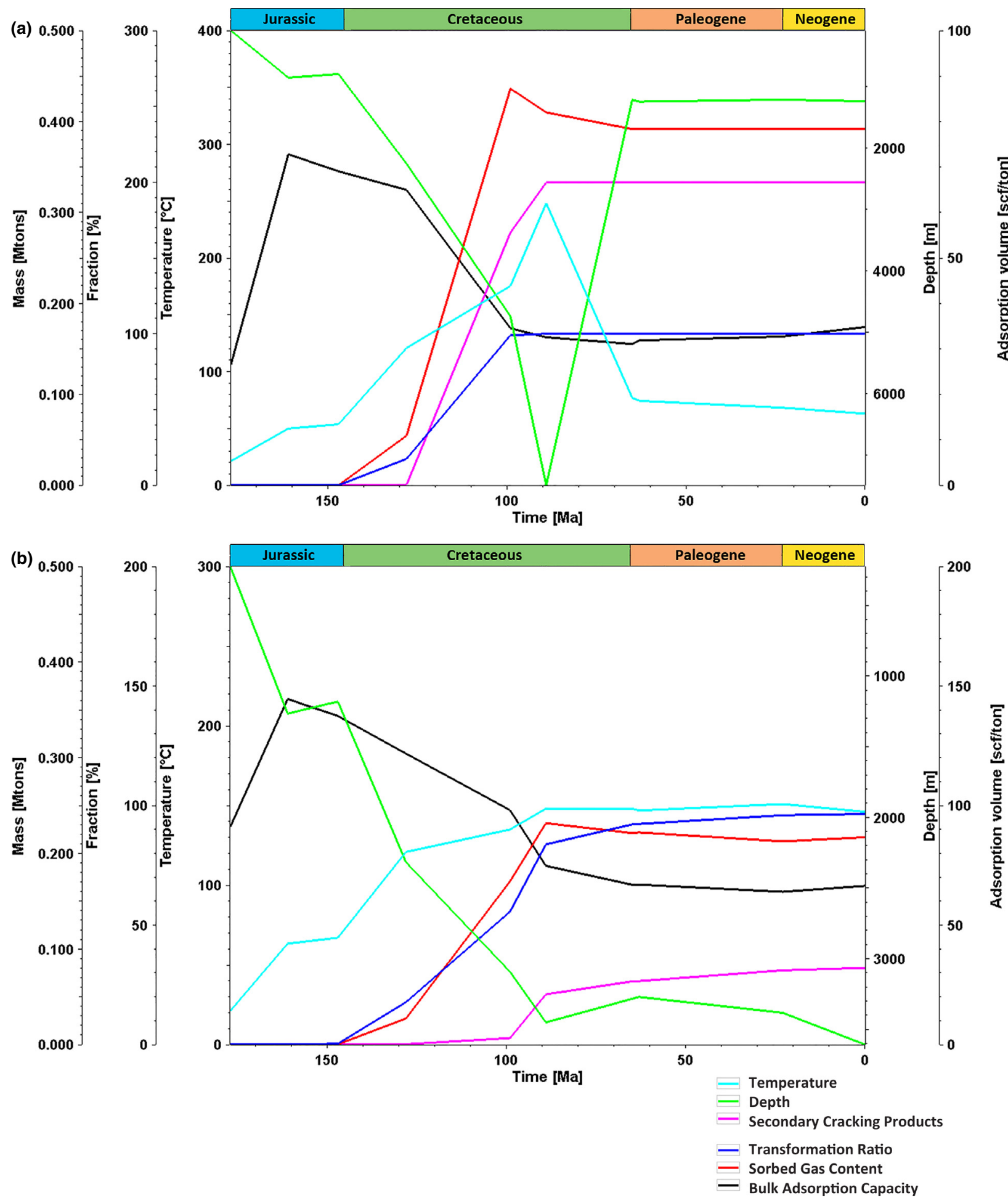

Fig. 16. Representative 1D time plots for the Lower Saxony Basin (a) and West Netherlands Basin (b) illustrating the differential evolution of the burial history and the corresponding changes in temperature, transformation ratio (TR), adsorption capacity, methane generation due to secondary cracking and total adsorbed gas contents of the Posidonia shale [bulk adsorption capacity $\left(10^{6 *}\right.$ tons); depth (m); TR (\%); secondary cracking products $\left(10^{6 *}\right.$ tons); sorbed volume of methane at standard conditions per mass of rock (scf ton ${ }^{-1}$ rock); temperature $\left.\left({ }^{\circ} \mathrm{C}\right)\right]$.

The possibility to implement this additional heat input within a basin especially effects former assumptions on basal heat flow which have been overestimated if radiogenic heat production had not been considered. As Ura- nium, Thorium and Potassium as major contributors to radiogenic heat can mainly be found in shales, the generated heat and effect on maturation strongly depends on the existing amount of shale or shaly lithologies in the 


\section{B. Bruns et al.}

(a)

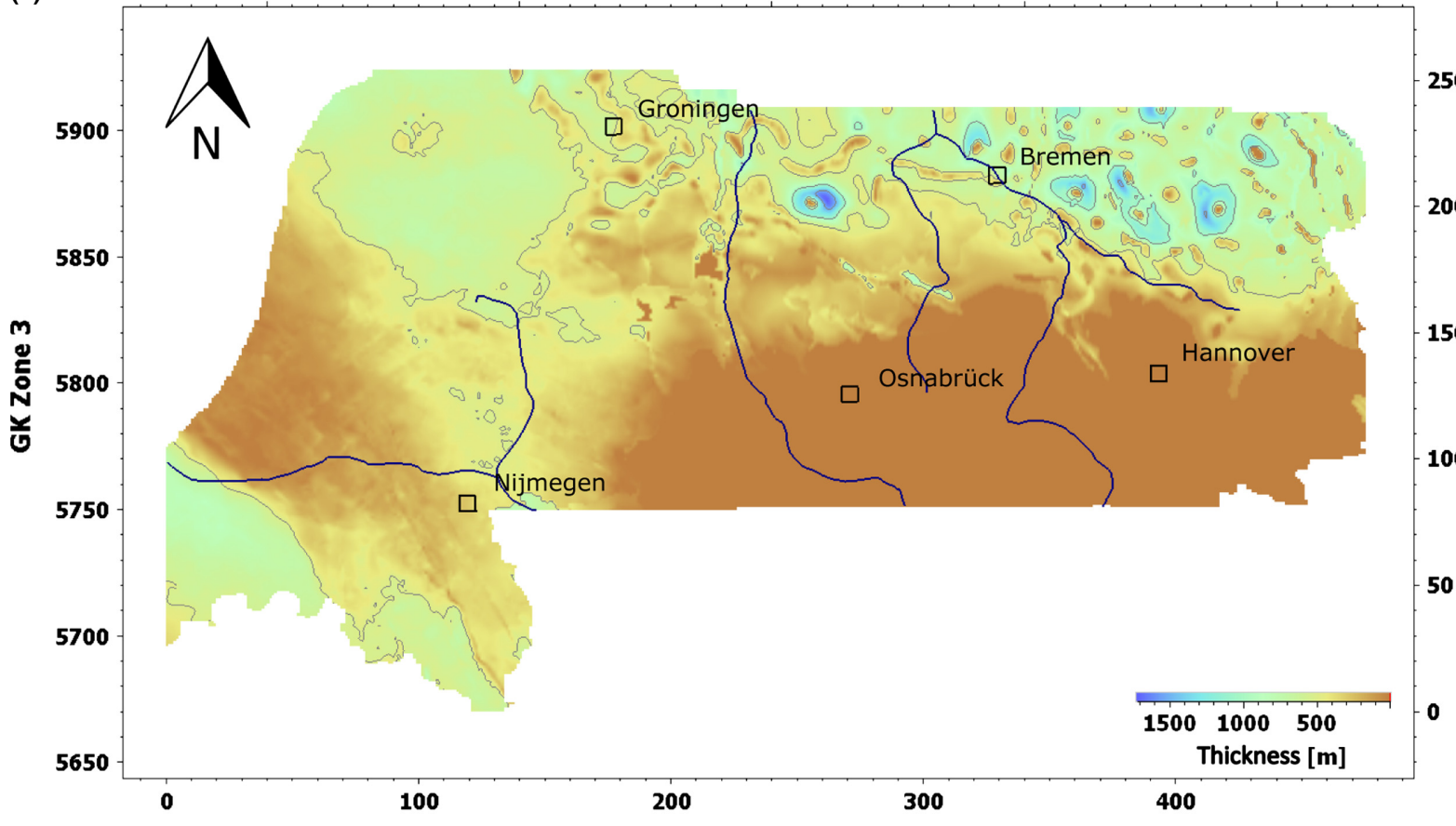

(b) 3400 3500 3600

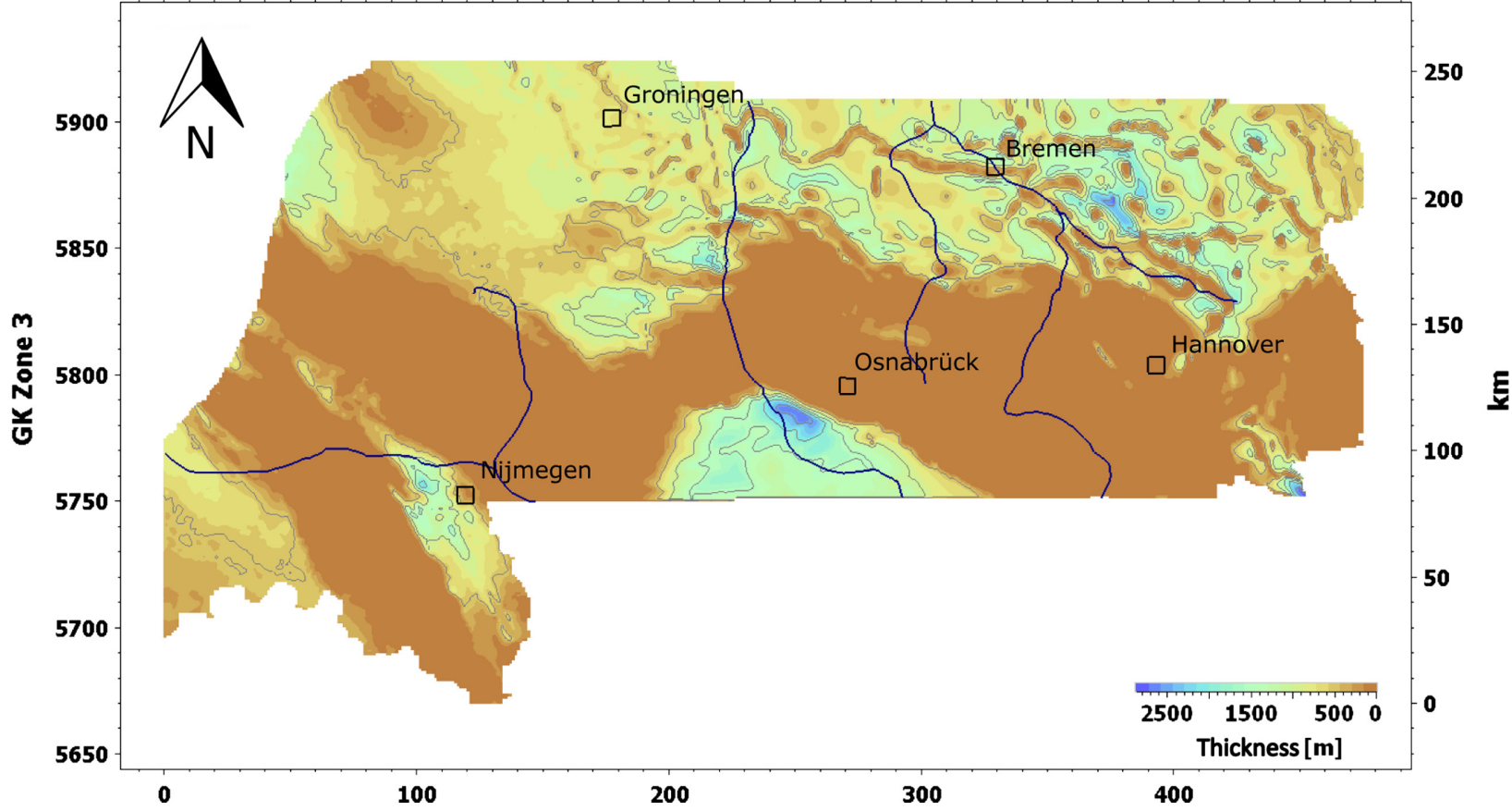

Fig. 17. Present-day Paleogene (a; $\left.26400 \mathrm{~km}^{3}\right)$ and Upper Cretaceous thickness (b; $34600 \mathrm{~km}^{3}$ ).

sedimentary column. Systematical comparison of modelling results regarding basal heat flows during time of deepest burial with former studies (e.g. Petmecky, 1998) in the Lower Saxony Basin has shown some differences. Basal heat flows (as well as burial depth) at these critical moments during deepest burial could be reduced and still yielding the same results regarding the present-day maturity level. This difference of course is only valid for the Lower Saxony Basin with its unique distribution of shale content and cannot necessarily be applied for other basins. Figure 19c illustrates this difference of deacti- vated radiogenic heat production of the original mix of user-defined lithologies (green line). Using basal heat flow scenario 2 and leaving the erosion amount constant the vitrinite reflectance trend has been simulated with and without radiogenic heat production. Results indicate that $\mathrm{VR}_{r}$ values differ on average by $20 \%$; that is higher basal heat flow and/or deeper burial is required to match the $\mathrm{VR}_{r}$ values if no internal radiogenic heat production is taken into account. In addition, the influence of shale content and its radiogenic heat production on the temperature field has been tested (Fig. 19c). By applying a pure 

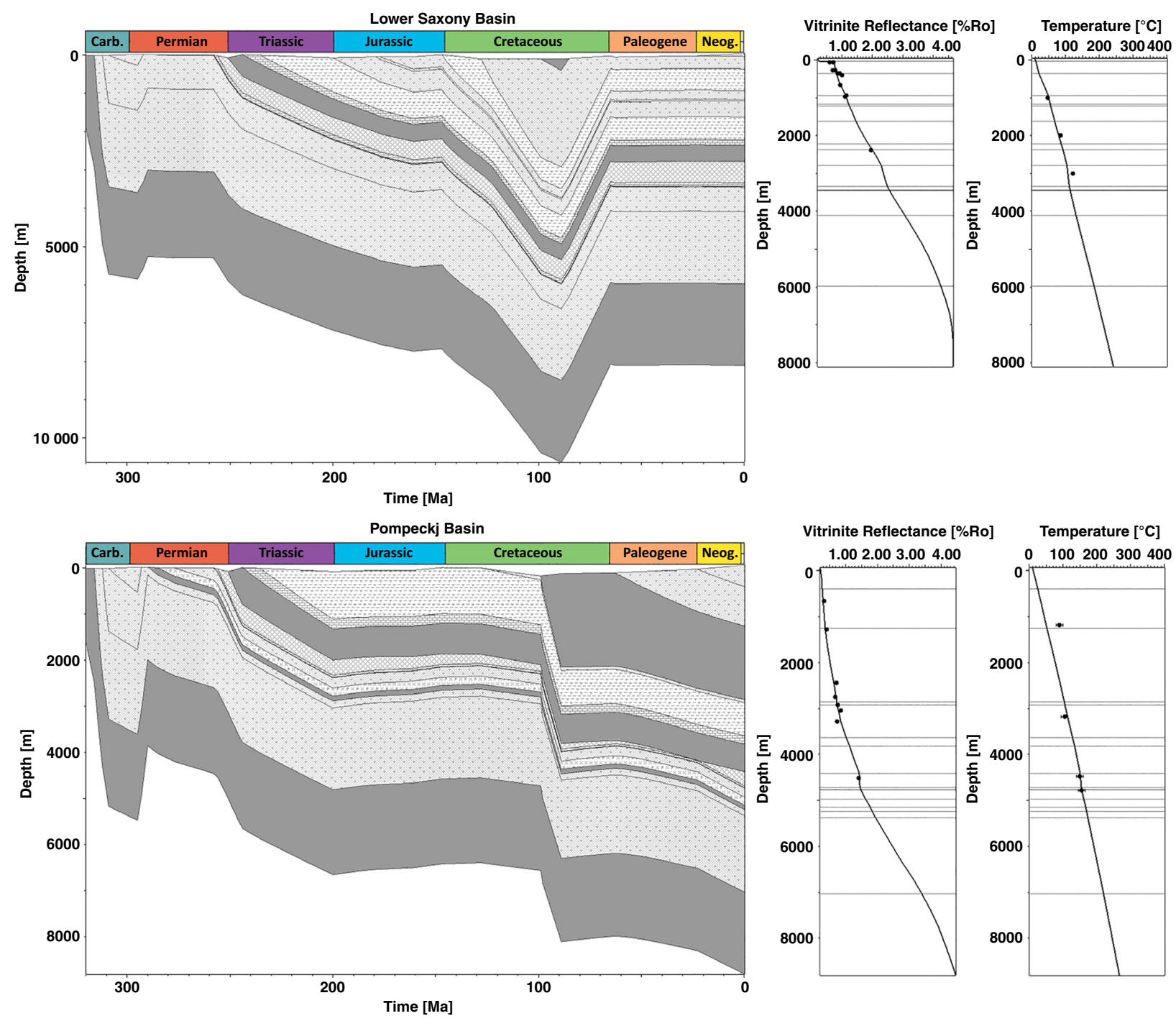

Fig. 18. 1D burial plots indicating the coupled timing of uplift and erosion in the Lower Saxony Basin with increasing sedimentation rate and layer thicknesses in adjacent accommodation areas as e.g. the Pompeckj Basin.

shale lithology to the sediment column above the Lower Triassic Buntsandstein, the effect of heat accumulation due to decreased thermal conductivity becomes apparent (red line). Deactivating the radiogenic heat production of the shale lithology leads to a reduced maturity (blue line). In conclusion, the effect of heat accumulation on maturity due to reduced thermal conductivity of shale is bigger than the influence by radiogenic heat production.

\section{Intrusion vs. inversion - Bramsche Massif}

A problem of regional importance is the thermal development of the inverted Lower Saxony Basin. It is still being controversially discussed whether present-day maturities especially in the southwestern part of the basin have developed in response to a deep-seated plutonic intrusion, the so-called Bramsche Massif, having ascended during the Late Cretaceous (e.g. Bartenstein et al., 1971; Teichmüller et al., 1979, 1984) up to present-day depths of $6 \mathrm{~km}$ (Brockamp, 1967; Stadler \& Teichmüller, 1971; Bilgili et al., 2009) or due to deep subsidence until the Late Cretaceous followed by uplift of the basin and widespread erosion of the basin infill (Senglaub et al., 2005, 2006; Adriasola-Muñoz et al., 2007; Brink, 2013; Bruns et al., 2013). Both, conspicuously anomalous gravimetric and magnetic attributes (Schmidt, 1914) as well as refraction seismics (Brockamp, 1967) were formerly interpreted as a result of a mafic intrusion body (Bartenstein et al., 1971; Stadler, 1971; Stahl, 1971). Many studies based on newly performed measurements and reinterpretation of formerly acquired data have shown that the old intrusion scenario has to be revised (e.g. John, 1975; Baldschuhn \& Kockel, 1999; Brink, 2002, 2013; Kockel, 2003; Senglaub et al., 2005, 2006; Adriasola-Muñoz et al., 2007; Bruns et al., 2013). The aim of the thermal and burial history reconstruction presented in this study is to aid in showing alternative inversion scenarios in contrast to the intrusion hypothesis.

It is without doubt that the anomalously basin-wide pattern of high maturities in the Lower Saxony Basin has been caused by high temperatures. Increased temperatures can develop through elevated heat flows (e.g. in the 


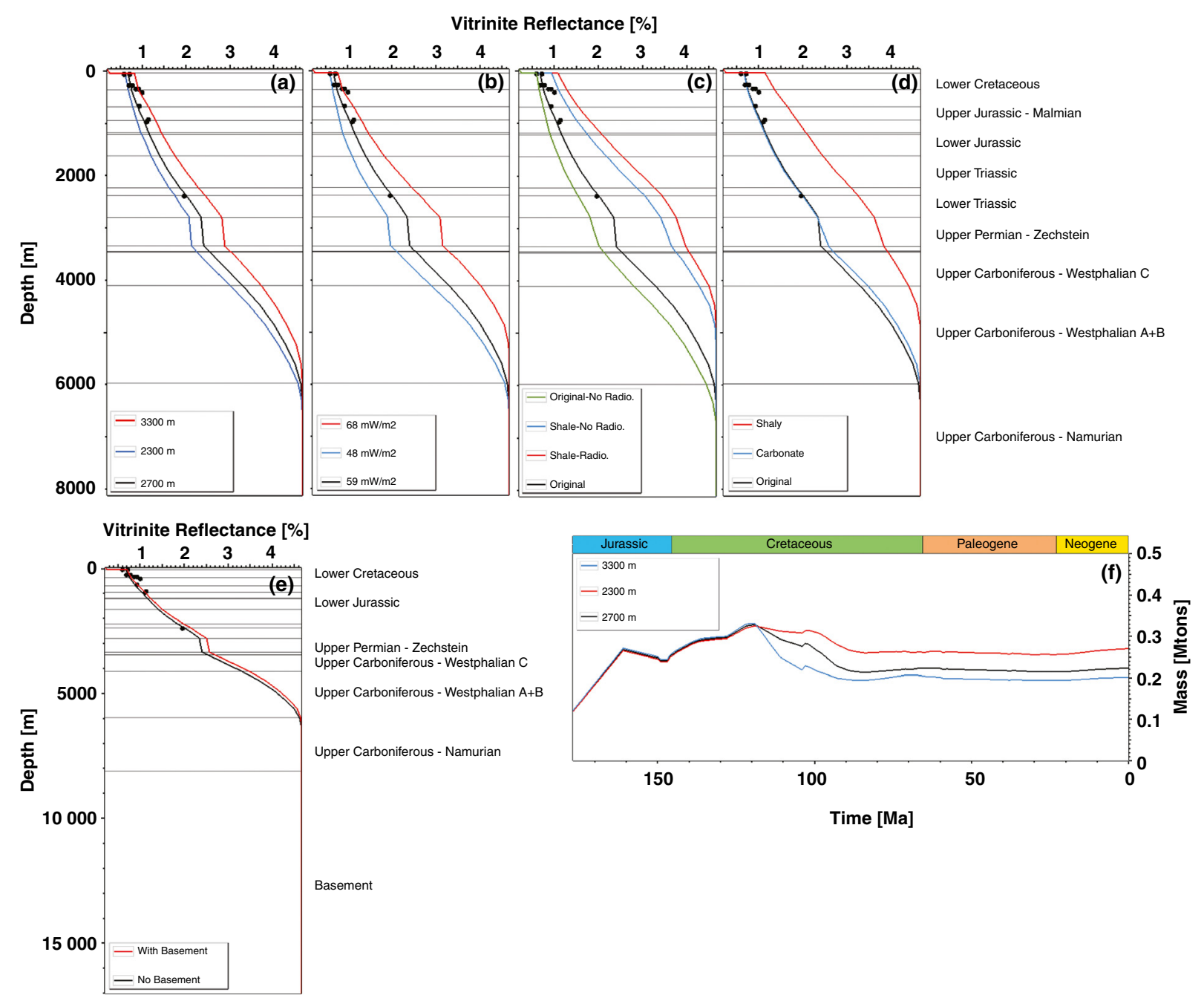

Fig. 19. Vitrinite reflectance vs. depth calibration plots (a-e) and bulk adsorption capacity vs. erosion/burial depth plot (f) for the well presented in Fig. 18 (top). Measured vitrinite reflectance data (points) and calibration curves (lines) have been calculated for (a) different erosional thickness with the heat flow trend displayed in Fig. 7 (Scenario 2); (b) different basal heat flow at time of deepest burial with an erosional thickness of $2700 \mathrm{~m}$; (c) the best-fit model in comparison to deactivated radiogenic heat production of the user-defined lithology mix and of a pure shale lithology for the sediment column above the Lower Triassic Buntsandstein; (d) the best-fit model including a single shale or carbonate lithology in comparison to the user-defined lithology applied to the eroded deposits; (e) the best-fit model with and without the radiogenic heat producing basement.

vicinity of a plutonic intrusion or due to crustal thinning) and/or through deep subsidence. These high maturities, however, cannot only be observed in corresponding depths where they would be expected regarding the regional temperature gradient but also near the surface of the basin mirroring reduced or even missing layer thicknesses in the basin area which are still present in the surrounding areas of the Lower Saxony Basin (Bruns et al., 2013). Here, especially in the southern part of the basin stratigraphically older strata had been uplifted to shallow depths and partly eroded. In addition, expected high $\mathrm{VR}_{r}$ gradients which would suit elevated heat flows caused by an intrusion can generally not be observed; most of the available vitrinite datasets of the Lower Saxony Basin (see VIDABA; Bruns et al., 2013) rather match a temperature evolution that was caused by deep subsidence. In addition, modelling approaches have shown that it is difficult to reach observed surface maturities with a large intrusion body at $6-10 \mathrm{~km}$ depth. Seismic velocity logs show high velocities indicating strongly compacted strata in and especially outside of that area (John, 1975; Brink, 2002) resulting in similar magnitudes of uplift as presented here. The observable density and gravitational anomaly in the area of the Bramsche Massif does not necessarily have to be an effect of a magmatic body (Bilgili et al., 2009) but could e.g. also hint towards compacted high-density strata and/or integrated granulitized/eclogitized lower crust which was uplifted to lower depths (Brink, 2013). New magnetotelluric measurements (Hoffmann et al., 2008; Brink, 2010, 2012) show no indication of a plutonic body exhibiting low electric conductivities and high electric impedance, respectively, above $15 \mathrm{~km}$ depth. Brink (2013), therefore, proposed further alternative scenarios which could be held responsible for the observed anomalous attributes. High electric conductivities in close proximity to the seismic refractor and the specific seismic 
velocities in that refractor, originally interpreted as the roof of the intrusion, might also indicate Lower Carboniferous/Upper Devonian shelf carbonates (Hoffmann et al., 2008; Doornenbal \& Stevenson, 2010) to which the observed seismic velocities would suit more. On top of these carbonates, Upper Carboniferous deposits with high organic content had been deposited. The electric conductivity of these organic-rich deposits has then been altered and increased during graphitization. This carbonate platform, however, would probably not solely be responsible for the gravimetric and magnetic anomalies observed. Therefore, supported by modelling studies of Petrini \& Podladchikov (2000) and Scheibe et al. (2005), Brink (2013) suggested an additional eclogite body of high density and magnetic susceptibility beneath the carbonate platform. This body would have been uplifted as part of the lower crust implying an incorporation of the basement into the inversion of the Lower Saxony Basin.

On the other hand, the possibility of partial melting of the lower/middle crust and a Permo-Carboniferous magmatic intrusion during the Permian extensional phase cannot be suspended. Vast and thick Permian volcanics can be found especially north and east of the basin (Breitkreuz et al., 2008; Maystrenko et al., 2010). It is, however, unlikely that high present-day maturities of strata deposited until then (e.g. Carboniferous for which calibration data was available) had already been reached at that time. Maturities of the Meso- and Cenozoic overburden could not have been reached by post-Permian burial to observed present-day depths. This burial anomaly indicates much higher temperatures than at present day to match the palaeo-temperature calibration data. Additionally, increased temperatures due to rising geothermally heated water at the Jurassic/Cretaceous boundary during rifting and initiation of the basin are common but the heating effect would be locally constrained and following the fault system. This could not cause the high maturities visible on such a basin-wide scale. During the Upper Cretaceous the Lower Saxony Basin underwent compression/transpression due to the Africa-Iberia-Europe convergence but extrusives, rising geothermally heated water and magmatic intrusions are statistically more common in extensional regimes (Chaussard \& Amelung, 2014) rendering the hypothesis of a magmatic intrusion developing during the Upper Cretaceous even more unlikely.

\section{Sorption}

Methane sorption capacity and its implementation in PETROMOD ${ }^{\circledR}$

In this study, the experimental methane sorption data for the Posidonia shale from the Hils syncline, NW-Germany (Gasparik et al., 2014) and unpublished sorption data for the Wealden were used to derive the input Langmuir parameters for the PETROMOD ${ }^{\circledR}$ simulation (Table 4). While in Gasparik et al. (2014) the adsorbed phase density $\left(\rho_{a d s}\right)$ was used as a fitting parameter, here the value for $\rho_{a d s}$ was fixed to $423 \mathrm{~kg} \mathrm{~m}^{-3}$ (i.e. liquid methane density at the boiling point; Table 4). This value is often used in the literature as an approximation for the adsorbed phase density (Busch \& Gensterblum, 2011). Although in the current version of the PETROMOD ${ }^{\circledR}$ software $\rho_{a d s}$ is not explicitly implemented as an input parameter, the value of $\rho_{a d s}$ significantly influences the other two parameters, $v_{L}$ and $p_{L}$. This is obvious from the relationship between the excess sorption (experimentally determined quantity) and the absolute sorption:

$$
\begin{aligned}
v_{a d s}^{\text {excess }} & =v_{a d s}^{\text {absolute }}\left(1-\frac{\rho_{g}(T, p)}{\rho_{a d s}}\right) \\
& =v_{L} \frac{p}{p+p_{L}(T)}\left(1-\frac{\rho_{g}(T, p)}{\rho_{a d s}}\right)
\end{aligned}
$$

where $\rho_{g}(T, p)$ is the bulk (free) gas density at given temperature $(T)$ and pressure $(p)$. The meaning of the 'excess' sorption is simply the amount of gas present within the pores that is in excess to the amount that would have been present if no sorption took place (this 'non-sorption' case is experimentally determined by helium expansion). The absolute sorption, on the other hand, designates the amount of condensed gas phase defined by its density $\left(\rho_{a d s}\right)$ and occupying the volume $\left(v_{a d s}\right)$ at the gas-solid interface. The excess sorption is determined experimentally and can be unambiguously represented by the three fitted $n_{L}, p_{L}$ and $\rho_{\text {ads }}$ parameters using Eqn (1). Different combinations of the three parameters can be obtained for a single isotherm depending on whether the $\rho_{a d s}$ is fixed (to some 'meaningful' value) or used as a free fitting parameter. On the other hand, the absolute sorption cannot be determined experimentally as there is no current technology that would allow $\rho_{a d s}$ and $v_{a d s}$ to be measured directly. At low pressures or at subcritical conditions, the absolute sorption can be reasonably approximated by the measured excess sorption as the bulk gas density $\rho_{g}(T, p)$ is negligibly small compared to the adsorbed phase density $\rho_{a d s}$ (i.e. the ratio $\rho_{g}(T, p) / \rho_{a d s}$ in Eqn 1 is $c a$. 0 ). At supercritical conditions, however, with increasing pressure the absolute sorption deviates increasingly from the measured excess sorption due to a significantly large $\rho_{g}(T$, $p$ ). For methane at pressures $>8 \mathrm{MPa}$, the excess sorption isotherms on shales often exhibit a maximum followed by a downward trend of excess sorption with increasing pressure (Gasparik et al., 2012, 2014) meaning that the bulk density $\rho_{g}(T, p)$ increases with pressure at higher rates than the adsorbed phase density $\rho_{a d s}$. Such isotherms with maxima can only be represented by the three-parameter excess sorption function $\left(n_{L}, p_{L}, \rho_{a d s}\right)$ which is a direct approximation to the experimental data (irrespective of the true physical meaning of the parameters). The sorption data $\left(v_{L}\right.$ and $\left.p_{L}\right)$ as implemented in the PetroMoD ${ }^{\circledR}$ software, thus represent the absolute sorption and are no longer unambiguous for the reasons discussed above.

In geologic situations, as a first-order approximation, the sorption capacity of a given shale (other rock properties being constant) is controlled by pressure 


\section{B. Bruns et al.}

and temperature. The simultaneous effect of pressure (increases the sorption capacity) and temperature (decreases the sorption capacity) can be illustrated in sorption capacity vs. depth plots. Such a plot for the Posidonia Shale $\left(\mathrm{VR}_{r}=1.5 \%\right)$ is shown in Fig. 20 for both absolute and excess sorption using the data in Table 4. A geothermal and hydrostatic gradient of $30^{\circ} \mathrm{C} \mathrm{km}^{-1}$ and $10 \mathrm{MPa} \mathrm{km}{ }^{-1}$, respectively and a surface temperature of $20^{\circ} \mathrm{C}$ were assumed. Figure 20 shows several important features. Firstly, the limit of experimental conditions is indicated as a corresponding depth interval at maximum experimental pressure $(25 \mathrm{MPa} \sim 2500 \mathrm{~m})$ and temperature $\left(150^{\circ} \mathrm{C} \sim 5000 \mathrm{~m}\right)$. The 'representativeness' of the experimental conditions for high-pressure/high-temperature sorption in gas shales is accordingly limited more by the extent of maximum experimental pressures than maximum experimental temperatures. Above this depth interval, the calculated sorption capacity must be extrapolated. Secondly, the figure shows clearly the difference between the excess and the absolute sorption capacity. The excess sorption capacity exhibits a maximum of $89 \mathrm{scf} \mathrm{t}^{-1}$ or $2.6 \mathrm{~m}^{3} \mathrm{t}^{-1}$ (standard cubic metres ton ${ }^{-1}$ for gas at $101.325 \mathrm{kPa}$ and $20^{\circ} \mathrm{C}$ ) at a depth of $c a .1000 \mathrm{~m}$ and falls steadily thereafter with further increase in depth. The absolute sorption capacity exceeds significantly the excess sorption capacity and reaches a maximum at a depth of $c a .2600 \mathrm{~m}$ followed by only a slight decrease with further increase in depth.

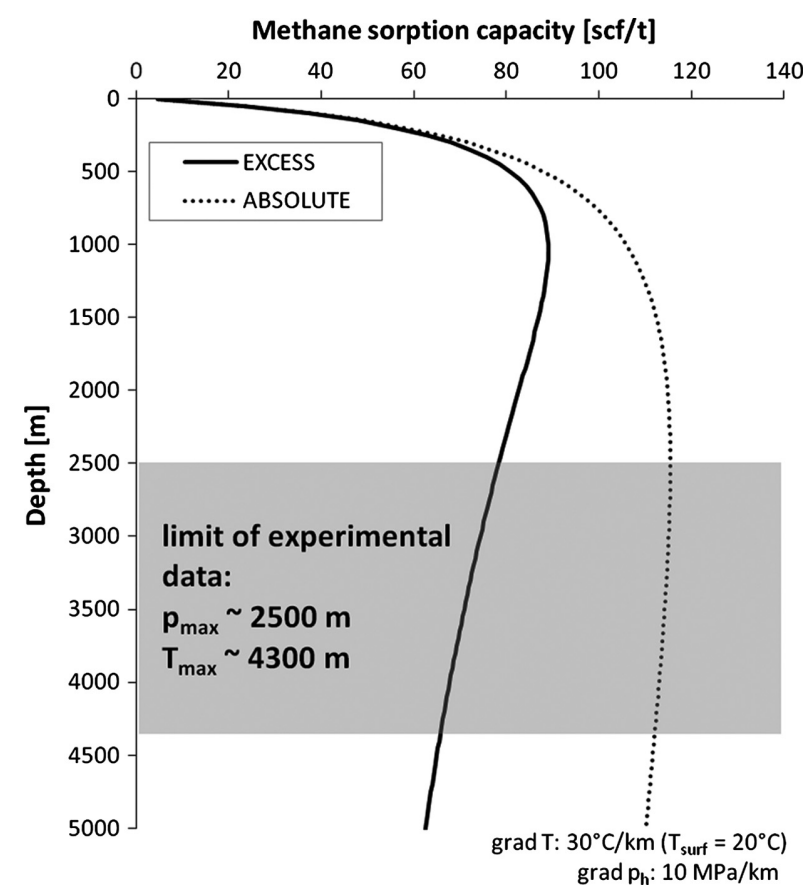

Fig. 20. Methane sorption capacity (excess and absolute) as a function of depth calculated from the experimental sorption data for the Posidonia Shale $\left(\mathrm{VR}_{r}=1.5 \%\right)$. A significant deviation between the excess and the absolute sorption (as used by PETroMOD ${ }^{\circledR}$ ) can be observed. The shaded area indicates the limit of experimental data. The geothermal and hydrostatic gradients as well as the surface temperature are indicated below the plot.
The use of absolute vs. excess sorption data has important implications for the uncertainties in estimation of Gas-In-Place (GIP) as already discussed by Ambrose et al. (2012). Using the definition of excess sorption, the total gas storage capacity is simply a sum of the excess sorption capacity and the free gas capacity which is a function of gas-filled porosity $\Phi_{0}$ :

$v_{\text {total }}(T, p)=v_{\text {ads }}^{\text {excess }}(T, p)+v_{\text {free }}\left(T, p, \Phi_{0}\right)$

However, when the absolute sorption data is used for calculating GIP instead, the calculation of the free gas storage capacity has to explicitly consider the reducing effect of the adsorbed molecules on the pore volume available for the free gas:

$v_{\text {total }}(T, p)=v_{\text {ads }}^{\text {absolute }}(T, p)+v_{\text {free }}\left(T, p, \Phi_{0}-\Phi_{a d s}\right)$

where $\Phi_{a d s}$ is the portion of the total gas-filled porosity taken up by the sorbed molecules. If this effect is ignored, the calculated total gas storage capacity will be overestimated by the amount equal to the difference between the absolute and the excess sorption capacity. Accordingly, and also referring to the discussion by Ambrose et al. (2012), the use of excess sorption should be preferred over absolute sorption in basin modelling or reservoir simulators as it is the closest representation of the experimental data and no volumetric corrections need to be made to the free gas component.

\section{Adsorption capacity and gas content during burial history}

The present-day gas quantities in a particular shale gas play result from a complex interplay between the amount of gas generated from the breakdown of organic matter (through thermogenic or biogenic processes) and the capacity of the rock to retain this gas. Basin modelling provides an effective tool to study gas generation and the evolution of the adsorption capacity and the gas content through burial history. It should be stressed here that the complexity of the unconventional petroleum system can hardly be captured by the model and therefore, the quantitative results should be interpreted with caution. In addition to the uncertainties related to the use of 'absolute' sorption discussed in the previous section, the characteristics of the pore system and hence the sorption capacity will change during the thermal maturation. For coals, these are well established observations (e.g. Hildenbrandt et al., 2006; Gensterblum et al., 2014). Recently published data on organic-rich shales by Gasparik et al. (2014) and Zhang et al. (2012) have shown that the sorption capacity and the thermodynamic sorption parameters change systematically with maturity. In addition, the presence of moisture has a strong impact reducing the sorption capacity due to a competitive sorption between the water and the gas (methane) molecules. In PetroMOD ${ }^{\circledR}$, only the TOC is used as a scaling parameter and the influence of maturity and moisture on the sorption capacity is not captured by the model. As the input 
experimental sorption data by Gasparik et al. (2014) are based on overmature $\left(\mathrm{VR}_{r}=1.5 \%\right)$ Posidonia Shale samples at dry conditions, the calculated sorption capacity should be regarded as a maximum scenario.

Based on the changes in pressure and temperature during the burial evolution in the Lower Saxony Basin and West Netherlands Basin, the results for the Posidonia Shale (Fig. 16) show that the sorption capacity increases initially up to a depth of $c a .1000 \mathrm{~m}$ for the Lower Saxony Basin and the West Netherlands Basin (compare with Fig. 20) and thereafter decreases reaching a minimum value at the maximum burial depth. In the Lower Saxony Basin where a significant uplift took place during the Upper Cretaceous the sorption capacity has remained rather constant since. This reflects the fact that the absolute sorption changes less with depth after reaching its maximum value (Fig. 20). This is also shown in Fig. 19f, where different maximum burial depths or erosion amounts, respectively and their influence on sorption capacity have been tested. Here, using the same basal heat flow trend, varying amounts between 2300 and $3300 \mathrm{~m}$ of layer thickness removed during the Subhercynian inversion of the Lower Saxony Basin illustrate the sensitivity of sorption capacity to changes in burial depth and respective compaction and porosity as well as burial temperature (compare with Fig. 20).

The gas content and the relative proportion of adsorbed and free gas depends on the amount of gas generated (TR) and the total storage capacity (sorbed gas + free gas). In PEtroMoD ${ }^{\circledR}$ simulation, the accumulation of adsorbed gas precedes that of free gas which starts accumulating when the generated gas exceeds the sorption capacity. In reality, however, the sorbed gas can only coexist in a thermodynamic equilibrium with the free gas component in the pore space (or dissolved gas in liquid). When the pore space is initially saturated with water, a free gas phase may form from the early gas as the dissolution of methane in water is very small and the sorption capacity can be as low as $40-50 \%$ of that for a dry shale. Within the oil generation window, the produced hydrocarbons drive the water out of the shale and the pore space becomes increasingly saturated with oil which can contain significant quantities of dissolved gas. The increasing partial gas pressure drives the oil expulsion as the maturation continues. Finally, due to secondary cracking of the retained oil and pyrobitumen, additional pore space is created for the free gas phase. Generation of secondary porosity due to thermal breakdown of organic matter is considered in PETROMOD ${ }^{\circledR}$, but the influence of core plugging by bitumen within the oil window and secondary porosity inside the kerogen and solid bitumen network are not. Further uncertainties in estimated porosity arise from mineral precipitation, as well as thermo-mechanical effects on the pore system during hydrocarbon generation and under the influence of effective stress. Such effects are still poorly understood and up to now very few experimental data have been published for shales (e.g. Eseme et al., 2007, 2012).

\section{Implications for shale gas potential and exploration risk}

Hao et al. (2013) have discussed the potential risks for shale gas exploration in China and indicated that the present-day gas amounts in gas-mature shales are primarily controlled by the loss of free gas during and after the peak gas window. Hence, relatively low expulsion efficiency during the maximum burial and little or no tectonic faulting during the uplift phase (for inverted basins) are beneficial for decreased exploration risk for shale gas. In fact, most of the high-maturity productive shales in the US have behaved as closed or semi-closed systems during and after the peak gas generation and have remained overpressured up to present.

The outcome of a petroleum system model simulation with respect to the present-day gas content and the relative abundance of free and adsorbed gas will therefore strongly depend on the properties of the adjacent lithologies and whether the source rock is modelled as open or closed (perfect seal) system. At great depths, the free gas component will be the dominant contributor to the total gas content as the sorption capacity is reduced at high temperatures. Hence, the adsorption cannot preserve this gas which can be expelled during the maximum burial or during subsequent uplift. Significant losses of free gas can lead to under-saturation during the uplift stage (Gensterblum et al., 2014).

The results presented in this study were obtained under the assumption of an open system (relatively permeable seals above the source rocks \& open model boundaries) and therefore represent a rather conservative scenario (under the aspect of open/closed-system behaviour). Figure 16 shows that the present-day gas content in the Posidonia Shale in that area of the Lower Saxony Basin is preserved at roughly the same level as at the end of hydrocarbon generation (TR $=100 \%$ ) before the maximum burial stage (100-89 Ma) prior to the uplift phase. The calculated portion of the adsorbed gas relative to the total gas is almost $100 \%$. However, this value should not be regarded as meaningful and the real value is likely to be $<60 \%$ at a given depth. The reason for this, as already mentioned earlier, is that PETROMOD ${ }^{\circledR}$ treats the adsorbed gas as an independent phase and the free gas can only exist when the adsorption capacity is exceeded. While this should not affect the total gas content, the relative proportion of free gas can be considerably underestimated. A similar situation exists in the West Netherlands Basin which has experienced much less uplift than the Lower Saxony Basin and for which the ratio of sorbed over total gas calculated is also almost 1 .

\section{CONCLUSIONS}

- Major prospective areas within the study area showing shale gas potential at present day are confined to the Lower Saxony Basin, southern Gifhorn Trough and West Netherlands Basin. 


\section{B. Bruns et al.}

- The distribution and thickness of the Wealden and Posidonia Shale has been reassessed, providing new source-rock thickness maps.

- Temperature history reconstruction and source-rock maturity evaluation are based on two different tectonic and thermal evolution scenarios incorporating major uplift events that affected the study area. Scenario 2 takes heat flow trends from published literature into account (higher heat flows during rifting/ thinning of the crust), whereas Scenario 1 has been compiled considering in addition the effect of uplifted hot crust during inversion and cooling by thick sedimentary piles during rapid sedimentation. At time of deepest burial prior to the Upper Cretaceous uplift the basal heat flow can differ by up to $17 \mathrm{~mW} \mathrm{~m}^{-2}$.

- High-resolution erosion maps are now available, especially for the Late Cretaceous inversion.

- During the Upper Cretaceous (89 Ma) the Posidonia Shale in the Lower Saxony Basin was characterized by burial depths as deep as $10000 \mathrm{~m}$ (Scenario 1) and $7800 \mathrm{~m}$ (Scenario 2) resulting in temperatures of up to $330^{\circ} \mathrm{C}$. Maturities in some parts of the Lower Saxony Basin depocentre reached the overmature state. The average maturation in the basin centre reached the dry gas stage $\left(>2.3 \% \mathrm{VR}_{r}\right)$, whereas the basin margin maturities remained in the oil window.

- Prior to the Subhercynian erosion the end of sedimentation in the West Netherlands Basin was only partly characterized by greatest burial depths. Average burial depths of the Posidonia Shale equalled $2600 \mathrm{~m}$ in the centre and $1600 \mathrm{~m}$ at the basin flanks. Temperatures ranged between 75 and $120^{\circ} \mathrm{C}$ resulting in maturities of $0.4-1.2 \% \mathrm{VR}_{r}$. Thus, large parts of the basin had reached the oil generation stage.

- The Subhercynian inversion induced strongest uplift and erosion of the Lower Saxony Basin removing up to $8950 \mathrm{~m}$ (Scenario 1) and $6800 \mathrm{~m}$ (Scenario 2) of basin infill. Today, the top of the Posidonia Shale can be found at depths of up to $3600 \mathrm{~m}$ with deepest locations in the northwestern West Netherlands Basin, northern Lower Saxony Basin and northeastern Pompeckj Basin.

- In the Central and West Netherlands basins the Subhercynian erosion removed up to $2900 \mathrm{~m}$ (Scenario 1) and 2200 (Scenario 2) of basin infill. Burial of the Posidonia Shale, especially in the southwestern part of the West Netherlands Basin, continued until present day. Burial depths of up to $3600 \mathrm{~m}$ result in temperatures of up to $140^{\circ} \mathrm{C}$ and maturities up to the late oil-early gas generation stage $\left(1.3 \% \mathrm{VR}_{r}\right)$.

- The Wealden in the Lower Saxony Basin was characterized by greatest burial depths of up to $7900 \mathrm{~m}$ (Scenario 1) and $5800 \mathrm{~m}$ (Scenario 2) resulting in temperatures of up to $260^{\circ} \mathrm{C}$. Maturities in some confined parts of the Lower Saxony Basin depocenter reached up to $3.7 \% \mathrm{VR}_{r}$; the average maturation in the basin centre reached the dry gas stage $(>2.3 \%$
$\mathrm{VR}_{r}$ ), whereas the basin margin maturities remained in the oil window. The Wealden-equivalent Coevorden Formation in the Netherlands still remained immature. The top of the Wealden at present day can be found at depths of up to $2700 \mathrm{~m}$. In large parts of the Lower Saxony Basin the top has been uplifted and is now only at a few hundred metres depth or even at the surface.

- Burial/inversion scenario 1 generally favours gas sorption in comparison to scenario 2. Due to deeper burial and lower temperature gradients, higher amounts of gas are expected.

- For the Posidonia Shale in the Lower Saxony Basin bulk adsorption capacities (note that bulk adsorption capacities are given for the total layer thickness within a grid cell size of $1 \mathrm{~km}^{2}$ ) of about $1.3 * 10^{6}$ tons and gas contents of up to $82 \mathrm{scf}^{-1} \mathrm{ton}^{-1}$ rock have been predicted. The capacities at the northern and eastern boundaries of the Lower Saxony Basin, Pompeckj Basin and Gifhorn Trough range around $2.5^{*} 10^{6}$ tons. In the West Netherlands Basin, capacities range between 1.2 and $2.8^{*} 10^{6}$ tons. In the southern area of the Gifhorn Trough and southwestern flank of the West Netherlands Basin, average gas contents of up to $95 \mathrm{scf}^{-1} \mathrm{ton}^{-1}$ rock have been predicted.

- Bulk adsorption capacity of the Wealden is highest in areas with increased layer thickness and ranges up to $27 * 10^{6}$ tons. Gas contents calculated for the Ems river area reach values up to $26 \mathrm{scf}^{-1}$ ton $^{-1}$ rock and for the Hunte river area up to $45 \mathrm{scf}$ ton $^{-1}$ rock.

\section{ACKNOWLEDGEMENTS}

This work was financially supported by the GASH - Gas Shales in Europe Initiative. The authors thank Schlumberger for providing an academic license of the PETROMOD ${ }^{\circledR}$ software package as well as Prof. Cynthia Ebinger, Dr. H.-J. Brink and an anonymous reviewer for providing constructive comments.

\section{REFERENCES}

Adriasola-Muñoz, Y., LitTke, R. \& Brix, M.R. (2007) Fluid systems and basin evolution of the western Lower Saxony Basin, Germany. Geofluids, 7, 335-355.

van Adrichem Boogaert, H.A. \& Kouwe, W.F.P. (1993) Stratigraphic nomenclature of the Netherlands, revision and update by RGD and NOGEPA. Meded. Rijks Geol. Dienst, 50, 1-40.

Altebaeumer, F.J. (1982) Studies on hydrocarbon genesis in clay stones of the Upper Jurassic Delta (Pliensbachium) in the North West German Basin, with particular regard to the influence of the hot intrusive masses of Bramsche and Vlotho. Dissertation, RWTH Aachen University, Aachen.

Ambrose, R.J., Hartman, R.C. \& Diaz-Campos, M. (2012) Shale gas-in-place calculations part I: new pore-scale considerations. SPE F., 17(1), 219-229. 
Andruleit, H., Bahr, A., Bönnemann, C., Erbacher, J., Franke, D., Gerling, J.P., Gestermann, N., Himmelsbach, T., Kosinowski, M., Krug, S., Pierau, R., Pletsch, T., Rogalla, U., Schlömer, S. \& Niko-Projekt-Team (2012) Abschätzung des Erdgaspotenzials aus dichten Tongesteinen (Schiefergas) in Deutschland. Bundesanstalt für Geowissenschaften und Rohstoffe (BGR), Hannover.

Baldschunn, R. \& Kockel, F. (1999) Das Osning-Lineament am Südrand des Niedersachsen-Beckens. Zeitschrift der Deutschen Geologischen Gesellschaft, 150(4), 673-695.

Baldschunn, R., Kockel, F., Best, G., Deneke, E., Frisch, U., Juergens, U., Schmitz, J., Sattller-Kosinowski, S., Stancu-Kristoff, G. \& Zirngast, M. (1996) Geotektonischer Atlas von NW-Deutschland/Tectonic Atlas of NW-Germany 1:300 000. Bundesanstalt für Geowissenschaften und Rohstoffe (BGR), Hannover.

van Balen, R.T., Houtgast, R.F. \& Cloetingh, S.A.P.L. (2005) Neotectonics of the Netherlands; a review. In: Neotectonics and Quaternary Fault-Reactivation in Europe's Intraplate Lithosphere (Ed. by S.A.P.L. Cloetingh \& T.G.M. Cornu), pp. 439-454. Pergamon, Oxford.

Bartenstein, H., Teichmüller, M. \& Teichmüller, R. (1971) Die Umwandlung der organischen Substanz im Dach des Bramscher Massivs. Fortschr. Geol. Rheinl. u. Westf., 18, 501538.

Bilgili, F., Götze, H.-J., Pasteka, R., Schmidt, S. \& HackNEY, R. (2009) Intrusion versus inversion - a 3D density model of the southern rim of the Northwest German Basin. Int. F. Earth Sci., 98(3), 571-583.

Blumenstein, I.O., Krooss, B.M., di Primio, R., Rottke, W., Muller, E., Westerlage, C. \& Littke, R. (2008) Biodegradation in numerical basin modelling: a case study from the Gifhorn Trough, N-Germany. Int. 7. Earth Sci., 97, 11151129.

Breitkreuz, C., Geissler, M., Schneider, J. \& Kiersnowski, H. (2008) Basin initiation: volcanism and sedimentation. In: Dynamics of Complex Intracontinental Basins (Ed. by R. Littke, U. Bayer, D. Gajewski \& S. Nelskamp), pp. 173-180. Springer-Verlag, Berlin.

BrinK, H.-J. (2002) Die Anomalien von Bramsche, wieder eine offene Frage? Erdöl Erdgas Kohle, 118(1), 18-22.

BRINK, H.-J. (2010) Classification of the Central European Basin System (CEBS). DGMK Research Report, 577-2/4, pp. 63.

BRINK, H.-J. (2012) Kosmische Würfelspiele und die Entwicklung der Erde. Dinslaken (Athene Media), pp. 120.

BRINK, H.-J. (2013) Die Intrusion von Bramsche - ein Irrtum im invertierten Niedersächsischen Becken? Zeitschr. D. Ges. Geomiss., 164(1), 33-48.

BRockamp, B. (1967) Kurzbericht über die im Gebiet um Osnabrück durchgeführten seismischen Arbeiten des Instituts für Reine und Angewandte Geophysik der Universitat Münster. Veröff. Dt. Geodät. Komm., B153, 1-12.

Bruns, B., di Primio, R., Berner, U. \& Littke, R. (2013) Petroleum system evolution in the inverted Lower Saxony Basin, northwest Germany: a 3D basin modeling study. Geofluids, 13 (2), 246-271.

Büker, C., Littke, R. \& Welte, D.H. (1995) 2D-modeling of the thermal evolution of Carboniferous and Devonian sedimentary rocks of the eastern Ruhr basin and northern Rhenish Massif, Germany. Zeitschr. D. Ges. Geomiss., 146, 321-339.
Busch, A. \& Gensterblum, Y. (2011) CBM and CO2-ECBM related sorption processes in coal: a review. Int. F. Coal Geol., 87, 49-71.

Chaussard, E. \& Amelung, F. (2014) Regional controls on magma ascent and storage in volcanic arcs. Geochem. Geophys. Geosyst., 15(4), 1407-1418.

Cloetingh, S. \& Ziegler, P.A. (2007) Tectonic models for the evolution of sedimentary basins. In: Crust and Lithosphere Dynamics. Treatise on Geophysics, Vol. 6 (Ed. by A.B. Watts), pp. 485-611. Elsevier B.V., Amsterdam.

De Jager, J. \& GeluK, M.C. (2007) Petroleum geology. In: Geology of the Netherlands: Royal Netherlands Academy of Arts and Science (Ed. by T.E. Wong, D.A.J. Batjes \& J. De Jager), pp. 241-264. Elsevier, Netherlands.

Doornenbal, H. \& Stevenson, A., editors. (2010) Petroleum Geological Atlas of the Southern Permian Basin Area. EAGE Publications, b.v., Houten.

DrozdzewsKi, G. \& Wrede, V. (1994) Faltung und Bruchtektonik - Analyse der Tektonik im Subvariscikum. Fortschr. Geol. Rheinl. u. Westf., 38, 7-187.

Duin, E.J.T., Doornenbal, J.C., RijKers, R.H.B., Verbeek, J.W. \& Wong, T.E. (2006) Subsurface structure of the Netherlands - results of recent onshore and offshore mapping. Netherlands 7. Geosci., 85, 245-276.

Eseme, E., Urai, J.L., Krooss, B.M. \& Littke, R. (2007) Review of mechanical properties of oil shales: implications for exploitation and basin modelling. Oil Shale, 24(2), 159-174.

Eseme, E., Krooss, B.M. \& LitTke, R. (2012) Evolution of petrophysical properties of oil shales during high-temperature compaction tests: implications for petroleum expulsion. Mar. Pet. Geol., 31, 110-124.

Franke, W. (2000) The mid-European segment of the Variscides: tectonostratigraphic units, terrane boundaries and plate tectonic evolution. Geol. Soc. Spec. Publ., 179, 35-61.

Gasparik, M., Ghanizadeh, A., Bertier, P., Gensterblum, Y., Bouw, S. \& Krooss, B.M. (2012) High-pressure methane sorption isotherms of Black Shales from The Netherlands. Energy Fuels, 26(8), 4995-5004.

Gasparik, M., Bertie, R.P., Gensterblum, Y., Ghanizadeh, A., Krooss, B.M. \& Littke, R. (2014) Geological controls on the methane storage capacity in organic-rich shales. Int. $\mathcal{F}$. Coal Geol., 123, 34-51.

Geluk, M.C. (2007) Triassic. In: Geology of the Netherlands (Ed. by T.E. Wong, D.A.J. Batjes \& J. de Jager), pp. 85-106. Royal Netherlands Academy of Arts and Science, Netherlands.

Gensterblum, Y., Merkel, A., Busch, A., Krooss, B.M. \& LitTKE, R. (2014) Gas saturation and $\mathrm{CO}_{2}$ enhancement potential of coalbed methane reservoirs as a function of depth. Am. Assoc. Pet. Geol. Bull., 98(2), 395-420.

Gerling, P., Geluk, M.C., Kockel, F., LoKhorst, A., Lott, G.K. \& Nicholson, R.A. (1999a) NW European Gas Atlas - new implications for the Carboniferous gas plays in the western part of the Southern Permian Basin. Geol. Soc. Lond., Petr. Geol. Conf. Ser., 5, 799-808.

Gerling, P., Kockel, F. \& Krull, P. (1999b) Das Kohlenwasserstoff-Potential des PrÄwestfals im norddeutschen Becken Eine Synthese. DGMK Research Report, 433, Hamburg.

Glennie, K.W. (1986) Development of N.W. Europe's Southern Permian gas basin. Geol. Soc. Spec. Publ., 23, 3-22.

Hantschel, T. \& Kauerauf, A.I. (2009) Fundamentals of Basin and Petroleum Systems Modeling. Springer, Dordrecht. 


\section{B. Bruns et al.}

HaO, F., Zou, H. \& Lu, Y. (2013) Mechanisms of shale gas storage: implications for shale gas exploration in China. $A m$. $A s-$ soc. Pet. Geol. Bull., 97(8), 1325-1346.

Hecht, F., Hering, O. \& Knoblock, J. (1962) Stratigraphie, Speichergesteins-Ausbildung und Kohlenwasserstoff-Führung im Rotliegenden und Karbon der Tiefbohrung Hoya Z1. Fortschr. Geol. Rheinl. u. Westf., 3, 1061-1074.

Hildenbrandt, A., Kroos, B.M., Busch, A. \& Gaschnitz, R. (2006) Evolution of methane sorption capacity of coal seams as a function of burial history - a case study from the Campine Basin, NE Belgium. Int. 7. Coal Geol., 66(3), 179-203.

Hoffmann, N., Hengesbach, L., Friedrichs, B. \& Brink, H.-J. (2008) The contribution of magnetotellurics to an improved understanding of the geological evolution of the North German Basin - review and new results. Zeitschrift der Deutschen Gesellschaft für Geomissenschaften, 159(4), 591-606.

van Hoorn, B. (1987) Structural evolution, timing and tectonic style of the Sole Pit inversion. Tectonophysics, 137, 309-334.

de JAGER, J. (2007) Geological development. In: Geology of the Netherlands: Royal Netherlands Academy of Arts and Science (Ed. by T.E. Wong, D.A.J. Batjes \& J. de Jager), pp. 5-26. Elsevier, Netherlands.

JoHn, H. (1975) Hebungs- und Senkungsvorgänge in Nordwestdeutschland. Erdöl u. Kohle, Erdgas, Petrochemie, 28 (6), 273-277.

KLEY, J. \& VoigT, T. (2008) Late Cretaceous intraplate thrusting in central Europe: effect of Africa-Europe-Iberia convergence, not Alpine collision. Geology, 36, 839-842.

KocKeL, F. (2002) Rifting processes in NW-Germany and the German North Sea Sector. Neth. F. Geosci., 81, 149-158.

Kockel, F. (2003) Inversion structures in Central Europe expressions and reasons, an open discussion. Neth. F. Geosci., 82(4), 367-382.

Krzywiec, P. (2006) Structural inversion of the Pomeranian and Kuiavian segments of the Mid-Polish Trough - lateral variations in timing and structural style. Geol. Q., 51(1), 151-168.

Leischner, K. (1994) Kalibration simulierter Temperaturgeschichten. Dissertation, Berichte des Forschungszentrums Jülich, Jülich.

Leischner, K., Welte, D.H. \& Littke, R. (1993) Fluid inclusions and organic maturity parameters as calibration tools in basin modeling. Spec. Pub. - Norm. Petrol. Soc., 3, 161-172.

Leythaeuser, D., Littke, R., Radke, M. \& Schaefer, R.G. (1988) Geochemical effects of petroleum migration and expulsion from Toarcian source rocks in the Hils syncline area, NW-Germany. Org. Geochem., 13(1-3), 489-502.

LitTKe, R., Baker, D.R. \& Leythaeuser, D. (1988) Microscopic and sedimentologic evidence for the generation and migration of hydrocarbons in Toarcian source rocks of different maturities. Org. Geochem., 13, 549-559.

Littke, R., Bueker, C., Lueckge, A., Sachsenhofer, R.F. \& Welte, D.H. (1994) A new evaluation of palaeo-heat flows and eroded thicknesses for the Carboniferous Ruhr basin, western Germany. Int. F. Coal Geol., 26(3-4), 155-183.

Littke, R., Krooss, B.M., Idiz, E. \& Frielingsdorf, J. (1995) Molecular nitrogen in natural gas accumulations: generation from sedimentary organic matter at high temperature. $\mathrm{Am}$. Assoc. Pet. Geol. Bull., 79, 410-430.

LitTke, R., Jendrzejewsk, I.L., Lokay, P., Shuangeing, W. \& RullkötTER, J. (1998) Organic geochemistry and depositional history of the Barremian-Aptian boundary interval in the Lower Saxony Basin, northern Germany. Cretac. Res., 19, 581-614.
Littke, R., Bayer, U., Gajewski, D. \& Nelskamp, S. (2008) Dynamics of Complex Intracontinental Basins, 519 pp. Springer-Verlag, Berlin, Heidelberg.

Littke, R., Krooss, B., Uffmann, A.K., Schulz, H.M. \& Horsfield, B. (2011) Unconventional gas resources in the Paleozoic of Central Europe. Oil Gas Sci. Technol., 66 (6), 953-977.

de Lugt, I.R., van Wees, J.D. \& Wong, T.E. (2003) The tectonic evolution of the southern Dutch North Sea during the Paleogene: basin inversion in distinct pulses. Tectonophysics, 373, 141-159.

Marotta, A.M., Bayer, U., Scheck, M. \& Thybo, H. (2001) The stress field below the NE German Basin: effects indeuced by the Alpine collision. Geophys. F. Int., 144(2), F8-F12.

Maystrenko, Y., Bayer, U., Brink, H.-J. \& Littke, R. (2008) The Central European basin system - an overview. In: Dynamics of Complex Intracontinental Basins (Ed. by R. Littke, U. Bayer, D. Gajewski \& S. Nelskamp), pp. 15-34. SpringerVerlag, Berlin.

Maystrenko, Y., Bayer, U. \& Scheck-Wenderoth, M. (2010) Structure and evolution of the Central European Basin System according to 3D modeling. DGMK Research Report, 5772/2, Hamburg.

MCKENZIE, D. (1978) Some remarks on the development of sedimentary basins. Earth Planet. Sci. Lett., 40, 25-32.

Miller, K.G., Kominz, M.A., Browning, J.V., Wright, J.D., Mountain, G.S., Katz, M.E., Sugarman, P.J., Cramer, B.S., Christie-Blick, N. \& Pekar, S.F. (2005) The Phanerozoic record of global sea-level change. Science, 310, 12931298.

Nelskamp, S. (2011) Structural evolution, temperature and maturity of sedimentary rocks in the Netherlands: results of combined structural and thermal 2D modeling. Dissertation, RWTH Aachen University, Aachen.

Nelskamp, S., David, P. \& LittKe, R. (2008) A comparison of burial, maturity and temperature histories of selected wells from sedimentary basins in The Netherlands. Int. F. Earth Sci., 97, 931-953.

Neunzert, G.H., Gaupp, R. \& Littke, R. (1996) Absenkungsund Temperaturgeschichte paläozoischer und mesozoischer Formationen im Nordwestdeutschen Becken. Zeitschrift der Deutschen Geologischen Gesellschaft, 147, 183-208.

Oncken, O., Plesch, A., Weber, J., Ricken, W. \& Schrader, S. (2000) Passive margin detachment during arc-continent collision (Central European Variscides). Geol. Soc. Spec. Publ., 179, 199-216.

Pepper, A.S. \& Corvi, P.J. (1995a) Simple kinetic models of petroleum formation. Part I: oil and gas generation from kerogen. Mar. Pet. Geol., 12(3), 291-319.

Pepper, A.S. \& Corvi, P.J. (1995b) Simple kinetic models of petroleum formation. Part II: oil-gas cracking. Mar. Pet. Geol., 12(3), 321-340.

Petmecky, S.P. (1998) Numerische Simulation der Entwicklungsgeschichte des zentralen Niedersächsischen Beckens unter besonderer Berücksichtigung der Erdgaslagerstätten-Bildung. Dissertation, Berichte des Forschungszentrums Jülich, Jülich.

Petmecky, S.P., Meier, L., Reiser, H. \& Littke, R. (1999) High thermal maturity in the Lower Saxony Basin: intrusion or deep burial? Tectonophysics, 304, 317-344.

Petrini, K. \& Podladchikov, Y. (2000) Lithospheric pressuredepth relationship in compressive regions of thickened crust. 7. Metamorph. Geol., 18, 67-77. 
di Primio, R. \& Horsfield, B. (2006) From petroleum type organofacies to hydrocarbon phase prediction. Am. Assoc. Pet. Geol. Bull., 90(7), 1031-1058.

Resak, M., Narkiewicz, M. \& Littke, R. (2008) New basin modeling results from the Polish part of the Central European Basin system: implications for the Late CretaceousEarly Paleogene structural inversion. Int. F. Earth Sci., 97, 955-972.

Rippen, D., Littke, R., Bruns, B. \& Mahlstedt, N. (2013) Organic geochemistry and petrography of Lower Cretaceous Wealden black shales of the Lower Saxony Basin: the transition from lacustrine oil shales to gas shales. Org. Geochem., 63, $18-36$.

Scheibe, R., Seidel, K., Vormbaum, M. \& Hoffmann, N. (2005) Magnetic and gravity modelling of the crystalline basement in the North German Basin. Zeitschrift der Deutschen Gesellschaft für Geomissenschaften, 156(2), 291-298.

SCHeIDT, G. \& LitTKe, R. (1989) Comparative organic petrology of interlayered sandstones, siltstones, mudstones and coals in the Upper Carboniferous Ruhr basin, Northwest Germany, and their thermal history and methane generation. Geol. Rundsch., 78, 375-390.

Schmidt, A. (1914) Die magnetische Vermessung I. Ordnung des Königreichs Preußen 1898-1903 nach den Beobachtungen von M. Eschenhagen und 7. Edler, Vol. 276, pp. 43. Veröffentlichung des Königlich-Preussischen Meteorologischen Instituts, Berlin (Behrend).

Schwarzer, D. \& Littke, R. (2007) Petroleum generation and migration in the 'Tight Gas' area of the German Rotliegend natural gas play: a basin modeling study. Petrol. Geosci., 13, $37-62$.

Schwarzkopf, T. (1987) Herkunft und Migration des Erdöls in ausgewählten Dogger beta Lagerstätten des Gifhorner Troges: Wechselwirkungen zwischen Kohlenwasserstoffgenese und Sandsteindiagense. Dissertation, RWTH Aachen, Aachen.

Senglaub, Y., Brix, M.R., Adriasola, A.C. \& Littke, R. (2005) New information on the thermal history of the southwestern Lower Saxony Basin, northern Germany, based on fission track analysis. Int. F. Earth Sci., 95(5-6), 876-896.

Senglaub, Y., LitTke, R. \& BRix, M.R. (2006) Numerical modelling of burial and temperature history as an approach for an alternative interpretation of the Bramsche anomaly, Lower Saxony Basin. Int. F. Earth Sci., 95, 204-224.

Stadler, G. (1971) Die Vererzung im Bereich des Bramscher Massivs und seiner Umgebung. Fortschr. Geol. Rheinl. Westf., $18,439-500$.

Stadler, G. \& Teichmüller, R. (1971) Zusammenfassender Überblick über die Entwicklung des Bramscher Massivs und des Niedersächsischen Tektogens. Fortschr. Geol. Rheinl. u. Westf., 18, 547-564.

STAHL, W. (1971) Isotopen-Analysen an Carbonaten und Kohlendioxid-Proben aus dem Einflußbereich und der weiteren Umgebung des Bramscher Intrusivs und an hydrothermalen Carbonaten aus dem Siegerland. Fortschr. Geol. Rheinl. u. Westf., 18, 429-438.
Stampfli, G.M. \& Borel, G.D. (2004) The TRAnSMED Transects in space and time: constraints on the Paleotectonic evolution of the Mediterranean domain. In: The TRANSMED Atlas, the Mediterranean Region from Crust to Mantle (Ed. by W. Cavazza, F.M. Roure, G.M. Stampfli \& P.A. Ziegler), pp. 52-80. Springer, Berlin, Heidelberg.

Sweeney, J.J. \& Burnham, A.K. (1990) Evaluation of a simple model of vitrinite reflectance based on chemical kinetics. Am. Assoc. Pet. Geol. Bull., 74, 1559-1570.

Teichmüller, R. \& Teichmüller, M. (1985) Inkohlungsgradienten in der Anthrazitfolge des Ibbenbürener Karbons. Fortschr. Geol. Rheinl. u. Westf., 33, 231-253.

Teichmüller, M., Teichmüller, R. \& Bartenstein, H. (1979) Inkohlung und Erdgas in Nordwestdeutschland. Eine Inkohlungskarte der Oberfläche des Oberkarbons. Fortschr. Geol. Rheinl. u. Westf., 27, 137-170.

Teichmüller, M., Teichmüller, R. \& Bartenstein, H. (1984) Inkohlung und Erdgas - eine neue Inkohlungskarte der Karbon-Oberfläche in Nordwestdeutschland. Fortschr. Geol. Rheinl. u. Westf., 32(1), 4-34.

Uffmann, A.K., Bruns, B. \& LitTke, R. (2010) Dynamics of the Central European Basin System (CEBS): large scale models of the Paleozoic petroleum system in the North German Basin. DGMK Research Report, 577-2/3, Hamburg.

Uffmann, A.K., Littke, R. \& Rippen, D. (2012) Mineralogy and geochemistry of Mississippian and Lower Pennsylvanian Black Shales at the Northern Margin of the Variscan Mountain Belt (Germany and Belgium). Int. F. Coal Geol., 103, 92108.

Van Wees, J.D., Stephenson, R.A., Ziegler, P.A., Bayer, U., McCann, T., Dadlez, R., Gaupp, R., Narkiewicz, M., BitZER, F. \& SCHECK, M. (2000) On the origin of the southern Permian Basin, Central Europe. Mar. Pet. Geol., 17, 43-59.

van Wees, J.D., Van Bergen, F., David, P., Nepveu, M., Beekman, F., Cloetingh, S. \& Bonté, D. (2009) Probabilistic tectonic heat flow modeling for basin maturation: assessment method and applications. Mar. Pet. Geol., 26, $536-551$.

WeHNER, H. (1997) Source and maturation of crude oils in northern and eastern Germany - an organic geochemical approach. Geol. Fahrb., Reihe D., 103, 85-102.

Wygrala, B.P. (1989) Integrated Study of an Oil Field in the Southern Po Basin, Northern Italy, pp. 2313. Berichte Kernforschungsanlage Jülich, Jülich.

Zhang, T., Ellis, G.S., Ruppel, S.C., Milliken, K. \& Yang, R. (2012) Effect of organic-matter type and thermal maturity on methane adsorption in shale-gas systems. Org. Geochem., 47, 120-131.

Ziegler, P.A. (1990) Geological Atlas of Western and Central Europe. 2nd edn, Shell International, The Hague.

Ziegler, P.A., Cloetingh, S. \& van Wees, J.D. (1995) Dynamics of intra-plate compressional deformation: the Alpine foreland and other examples. Tectonophysics, 252, 7-59.

Manuscript received 5 May 2014; In revised form 13 October 2014; Manuscript accepted 16 October 2014. 